\title{
IMF STRUCTURAL CONDITIONALITY: How Much Is Too Much?
}

\author{
Morris Goldstein \\ Dennis Weatherstone Senior Fellow, \\ Institute for International Economics
}

\section{Revision of paper presented at \\ NBER Conference on}

"Economic and Financial Crises in Emerging Market Economies"

Woodstock, Vermont

19-21 October 2000

I am grateful to Masood Ahmed, Mark Allen, Caroline Atkinson, C. Fred Bergsten, Barry Eichengreen, Marty Feldstein, Stanley Fischer, Tim Geithner, Stefan Ingves, Paul Keating, Mohsin Khan, Robert Lafrance, Carl Lindgren, Robert Litan, Michael Mussa, Yung Chul Park, Jacques Polak, James Powell, Miguel Savastano, Todd Stewart, Ohno Wijnholds, John Williamson, and Yukio Yoshimura for helpful comments on an earlier draft, and to Trond Augdal for superb research assistance. I also want to thank Stanley Fischer and his colleagues at the IMF for sharing with me the Fund's data on structural conditions in Fund programs. 


\section{INTRODUCTION}

“... detailed conditionality (often including dozens of conditions) has burdened IMF programs in recent years and made such programs unwieldy, highly conflictive, time consuming to negotiate, and often ineffectual."

"The IMF should cease lending to countries for long-term development assistance (as in sub-Saharan Africa) and for long-term structural transformation (as in post-Communist transition economies)... The current practice of extending long-term loans in exchange for member countries' agreeing to conditions set by the IMF should end."

Meltzer Report [2000, pp. 7,8, and 43]

"Both the Fund and the Bank have tried to do too much in recent years, and they have lost sight of their respective strengths. They both need to return to basics... [The Fund] should focus on a leaner agenda of monetary, fiscal, and exchange rate policies, and of banking and financial-sector surveillance and reform."

Council on Foreign Relations Task Force Report [1999, p. 18-19]

"The one common theme that runs through perceptions of ESAF at the country level is a feeling of a loss of control over the policy content and the pace of implementation of reform programs."

External Evaluation of the ESAF [Botcheway et al, 1998, p. 20]

"The IMF should eschew the temptation to use currency crises as an opportunity to force fundamental structural and institutional reforms on countries, however useful they may be in the long term, unless they are absolutely necessary to revive access to international funds."

Martin Feldstein [1998, p. 32]

“..the IMF's activities are not related to those specified in its charter for the simple reason that the par-value system of exchange rates it was to monitor no longer exists. In the tradition of skilled bureaucracies, the IMF has turned to new areas and has managed to expand substantially its financial resources and, in the process, its influence."

$$
\text { George Shultz [1995, p.5] }
$$

"The IMF has not been established to give guidance on social and political priorities, nor has its voting system been designed to give it the moral authority to oversee priorities of a noneconomic nature. Its functions have to be kept narrowly technical.....and the Fund has to accept that the authorities of a country are the sole judges of its social and political priorities."

$$
\text { David Finch [1983, pp. 77-78] }{ }^{2}
$$

\footnotetext{
${ }^{1}$ ESAF is the Fund's Enhanced Structural Adjustment Facility, established in 1987 to provide long-term concessional assistance to low-income countries facing protracted balance-of-payments problems.
} 
“... the IMF programs in East Asia are far from optimal for restoring financial market confidence in the short term.... they have covered a very wide range of policies beyond the immediate financial crisis.... Most of the structural reforms, however, simply detract attention from the financial crisis. They have taken government expertise, negotiating time, and political capital away from the core issues of financial markets, exchange rate policy, and the like."

$$
\text { Steve Radelet and Jeff Sachs [1998, pp. 67-68] }
$$

"In view of the size of the current deficits and the difficulties that may arise in private intermediation, the Fund must be prepared, when necessary, to lend in larger amounts than in the past. Also, the structural problems faced by many countries may require that adjustment take place over a longer period than has been typical in the frame work of Fund programs in the past."

IMF World Economic Outlook [1980]

"The Fund approach to adjustment has had severe economic costs for many of these [developing] countries in terms of declines in the levels of output and growth rates, reductions in employment and adverse effects on income distribution."

Report by the Group of Twenty-Four [1987, p. 9]

"Our prime objective is growth. In my view, there is no longer any ambiguity about this. It is towards growth that our programs and their conditionality are aimed."

"Only the pursuit of 'high-quality' growth is worth the effort. What is such growth? It is growth that can be sustained over time without causing domestic and external financial imbalance; growth that has the human person at its center... growth that, to be sustainable, is based on a continuous effort for more equity, poverty alleviation, and empowerment of poor people; and growth that promotes protection of the environment, and respect for national cultural values. This is what our programs are, more and more, and must aim for."

From speeches by former IMF Managing Director, Michel Camdessus. [1990, 2000a, respectively]

"In recent years, some critics of the IMF have gone to the opposite extreme, arguing that the IFIs should have done more, especially in the context of the economies in transition to develop an appropriate framework of property rights in support of markets.... in considering the future of the two institutions, their activities need to be geared to strengthening the private sector and the appropriate role of government in relation to it."

Anne Krueger [1998, p. 2003]

\footnotetext{
${ }^{2}$ Mr. Finch was then the Director of the IMF's Exchange and Trade Relations Department
} 
. "I do not accept the view that when it comes to our poorer member countries, we should not be lending to them, but should turn it over to someone else.... Is the poverty reduction and growth facility ... which we are working on jointly with the World Bank ... going to be an improvement in the way we deal with countries? Absolutely. Why? Because ... it forces us, in cooperation with the World Bank, to make sure that the macroeconomic framework is consistent with what needs to be done for social reasons. Macroeconomic instability is bad for everyone everywhere... That is why we should remain in these countries.... But we cannot do that in a way that ignores the fact that poverty is the main problem confronting these countries, and that there must be massive efforts, spearheaded by the World Bank, to reduce poverty in these countries."

Stanley Fischer, IMF First Deputy Managing Director [2000a]

"A changed IMF is needed for the changed world we now have... As we look to the future we need to redouble our efforts to find better approaches if not answers to fundamental questions...How do we balance concerns about intrusiveness in national affairs and a desire to promote national ownership of reform programs with a desire to see governments take bolder steps to, for example, build stronger social safety nets, implement core labor standards, empower civil society groups, reduce the role of government in the economy, and address critical issues related to governance, corruption, and crony capitalism?"

\section{U.S. Treasury Secretary Summers [1999]}

“...the proposed eligibility criteria [for IMF lending in the Meltzer report] are too narrow. Even where they are met, they would be unlikely to protect economies from the broad range of potential causes of crises. The criteria focus on the financial sector, and yet even problems that surface in the financial sector often have their roots in deeper economic and structural weaknesses. One simply cannot predict with confidence what the next generation of crises will be and therefore we need to preserve the IMF's ability to respond flexibly to changing circumstances." U.S. Treasury Response to the Meltzer Report [2000a, p.17]

"A central part of the programs in the Asian crisis countries was an unprecedented body of structural reforms...The overriding question is whether it was appropriate to place so much emphasis on structural reform measures in the financial and corporate sectors... The answer is clearly yes."

IMF Report (Lane et al. [1999]) on Fund Programs in Indonesia, Korea, and Thailand

"... the bottom line of the 'era of the IFIs,' despite obvious shortcomings, has been an unambiguous success of historic proportions in both economic and social terms."

Minority Dissent, Meltzer Report (Bergsten et al. [2000, p. 111]) 
As suggested above, an active debate has long been underway -- and has intensified in the wake of the Asian crisis -- about the appropriate scope and intrusiveness of IMF policy conditionality. In this paper, I take up one key element of that debate, namely, the role of structural policies in IMF-supported adjustment programs. By "structural policies," I mean policies aimed not at the management of aggregate demand but rather at either improving the efficiency of resource use and/or increasing the economy's produc tive capacity. Structural policies are usually aimed at reducing/dismantling government-imposed distortions or putting in place various institutional features of a modern market economy. Such structural policies include, inter alia: financialsector policies; liberalization of trade, capital markets, and of the exchange rate system; privatization and public enterprise policies; tax and expenditure policies (apart from the overall fiscal stance); labor market policies; pricing and marketing policies; transparency and disclosure policies; poverty-reduction and social safety-net policies; pension policies; corporate governance policies (including anti-corruption measures); and environmental policies.

To set the stage for what follows, it is worth summarizing the main concerns and criticisms that have been expressed about the IMF's existing approach to structural policy conditionality. ${ }^{3}$ These typically take one or more of the following forms.

First, there is a worry that wide-ranging and micro-managed structural policy recommendations will be viewed by developing-country borrowers as so costly and intrusive as to discourage unduly the demand for Fund assistance during crises. ${ }^{4}$ Even

\footnotetext{
${ }^{3}$ Neither these concerns and criticisms, nor the counter-arguments outlined later in this section, should be interpreted as my own views. I provide my own summary assessment of past Fund structural conditionality in Section VI.

${ }^{4}$ See, for example, Feldstein [1998].
} 
though the cost of borrowing from the Fund (the so-called rate of charge) is much lower than the cost of borrowing from private creditors -- particularly during times of stress -we observe that developing countries usually come to the Fund "late in the day" when their balance-of-payments problems are already severe. ${ }^{5}$ This suggests that developing countries place a non-trivial shadow price on the policy conditions associated with Fund borrowing. The concern is that if these conditions become too onerous, emerging economies will wait even longer to come to the Fund (as Thailand did in 1997) and/or will turn to regional official crisis lenders that offer easier policy conditionality (e.g., in 1998 Malaysia was one of the first beneficiaries of low-conditionality Miyazawa Initiative funds, and Asian countries could eventually decide to elevate the infant ChiangMai swap arrangements into a full-fledged Asian Monetary Fund). ${ }^{6}$ The outcome -- so the argument goes -- would then be even more difficult initial crisis conditions, greater resort to the anti-social behavior that the Fund was established to prevent, and a tendency toward Gresham's Law of conditionality (where weak regional conditionality would drive out not only the unnecessary but also the necessary elements of Fund conditionality).

A second concern is that insistence on deep structural reforms in cases of illiquidity (rather than insolvency) will serve only to frighten private investors about the size of the problem, thereby rendering more difficult the restoration of confidence and the rollover of short-term capital flows that are the keys to resolving the liquidity crisis. ${ }^{7}$ No country (including the G-7 countries) is without some structural weaknesses but it is argued that

\footnotetext{
${ }^{5}$ The Fund's rate of charge averaged about 4.5 percent in 1997-2000; in contrast, emerging-market bond spreads (relative to U.S. Treasuries) have fluctuated from 375 to 1700 basis points since the outbreak of the Thai crisis in mid-1997.

${ }^{6}$ See Bergsten [2000] on regional financial initiatives in Asia.
} 
however desirable structural policy reforms may be for the performance of the economy over the longer term, it is a mistake to suggest that such reforms are indispensable to resolving the crisis (when they are not). Among the Asian crisis countries, Korea is identified as a case where solvency was never in question and where less emphasis on structural reform both in the diagnosis and the policy prescription would have produced a milder crisis.

Concern number three is with equal treatment of countries -- one of the Fund's key operating principles. Here, the argument is that the Fund has been asking for sweeping structural reforms from developing countries that it would not ask of industrial countries were the latter in similar circumstances. As Paul Volcker put it, "When the Fund consults with a poor and weak country, the country gets in line. When it cons ults with a big and strong country, the Fund gets in line. ${ }^{, 8}$ While differences across countries in economic and political power are a fact of life, the argument is that requiring developing countries to undertake more structural remedies (than would their industrial-country counterparts) undermines local "ownership" of Fund programs. It also works at cross-purposes from simultaneous efforts to forge a consensus on strengthening the international financial architecture in (mixed developing country/industrial-country) groups like the G-20 and the Financial Stability Forum.

Yet a fourth criticism is that permitting the Fund to stray from its core competence of macroeconomic and exchange rate policies into a host of structural policy areas results in poor crisis management, weakens the Fund's overall reputation for competent analysis and advice (with adverse spillovers for the credibility of its recommendations in core

\footnotetext{
${ }^{7}$ See Radelet and Sachs [1998].

${ }^{8}$ Volcker and Gyohten [1992].
} 
policy areas), and runs counter to a sensible division of labor and an application of comparative advantage among the various international financial institutions (IFIs). In this connection, critics have maintained: that the Fund bungled bank closures in Indonesia and precipitated a credit crunch in the crisis countries by requiring an unduly rapid increase in bank capitalization; ${ }^{9}$ that the Fund lacks both the expertise and staff resources to make timely and sound policy recommendations in areas as diverse as corporate governance, trade policy, privatization, poverty reduction, and environmental management; and that "mission creep" on the part of both the Fund and the Bank, cum a blurring of responsibilities between them, reduces the public and legislative support necessary to fund them adequately. ${ }^{10}$ Long-term structural reforms (at least outside the financial sector) and poverty reduction should be the main business of the World Bank -not of the Fund.

A fifth charge is that the way the Fund has been managing its structural policy conditionality is flawed. Specifically, the argument is that multiplication of structural performance conditions, the specification of "micro" policy measures, and the increasing reliance on (qualitative) structural benchmarks and program reviews (as monitors of policy performance) have combined both to increase the uncertainty facing Fund borrowers and to lower the incentive to follow through with structural reform. Performance criteria were instituted not only to assure the Fund that its financial resources were being used for the purposes intended but also to assure the borrowing country that if it undertook certain pre-specified policy actions it would be eligible to

\footnotetext{
9 See, for example, Stiglitz [1999].

10 See Council on Foreign Relations [1999].
} 
draw. ${ }^{11}$ Also, because performance criteria were relatively few in number, easily measured, and macro in their impact, they both conveyed a relatively clear message about which policy actions were deemed (by the Fund) to carry the highest priority and provided a fairly predictable link with bottom-line economic outcomes (e.g., improvement in the balance of payments). But when a Fund program contains say, on the order of 50 or more qualitative structural policy conditions, when many of these conditions are very micro in nature, and when both fulfillment of these conditions and eligibility to draw require judgmental calls by the Fund, signals, impacts, and incentives will be more muddled. Should meeting 30 of 50 structural policy conditions be interpreted as a "good overall effort" that merits Fund support, or should it be viewed as a significant non-compliance with the program?

Suffice to say that these criticisms of the Fund's structural policy conditionality have not gone unchallenged. Again, in the spirit of motivating the subsequent discussion, it is well to consider the following counter-arguments.

Although the structural policy conditions the Fund attaches to its loans are often demanding and threaten vested interests within the country, emerging economies recognize that a Fund program represents their best chance to make real traction on the structural weaknesses that have underpinned their crisis vulnerability. Private capital markets, while they sometimes supply strong disciplining force, are not perfect substitutes for either the Fund's specific policy advice or its financing; indeed, in more than a few cases, private creditors will not extend credit in large amounts until the Fund

\footnotetext{
${ }^{11}$ See Guitian [1981] and Polak [1991].
} 
has blessed a country's policies. ${ }^{12}$ Turning the steering wheel over temporarily to an outside party is always costly but better the Fund than one or two large G-7 countries. Ironically, the structural policy measures that have drawn the most critical fire in several of the Asian crisis countries (Indonesia and Korea) were for a long time high on the priority list of domestic reformers, but they could not get those reforms implemented (over the opposition of the ruling elite) in a non-crisis situation. ${ }^{13}$ At this point, there is no plan to turn Asian swap or credit arrangements into a serious rival to the Fund, at least with respect to offering large bail-outs under competing policy conditionality. Also, very few crisis countries (in Asia or elsewhere) have seen capital controls as the preferred mode of crisis management. Just as it's not optimal for a host country to establish the weakest regulatory and prudential regime simply because it gives market participants the most freedom of action, it is not optimal (from the viewpoint of developing countries) to make Fund structural policy conditionality too easy or flexible. Fund "gaitsu" -- warts and all -- may still the best option out there for jump-starting structural reform.

The distinction between illiquidity and insolvency is not regarded as particularly helpful in most crisis situations since the dividing line between the two often rests on the quality of crisis management, and since countries differ from firms both in the nature of the relevant collateral and in their willingness (as opposed to ability) to pay. ${ }^{14}$ While investor panic was an important part of the Asian crisis story, so too were "bad

\footnotetext{
${ }^{12}$ Fischer [2000a, p. 1] argues that the fundamental reason why one needs an institution like the IMF is that “... the international financial system left to itself does not work perfectly, and it is possible to make it work better for the sake of the people who live in that system." Also, see Masson and Mussa [1995] and Krueger [1998]. Rodrik [1995] notes that an experiment in which private creditors attempted to specify and monitor conditionality in Peru was soon discontinued.

${ }^{13}$ See Haggard [2000]. On the role of domestic reformers in the Asian crisis countries, he concludes as follows: “....it is misguided to see the course of policy solely as a response to external political pressures from the international financial institutions and the United States... At least in some important policy areas, domestic groups were reaching surprisingly similar conclusions on the need for reform.” (p. 12).
} 
fundamentals" that increased downside risk. For example, in the run-up to the Korean crisis: 7 of the 30 largest chaebol were essentially bankrupt; there were large terms of trade losses in 1996 (especially for semi-conductors); non-performing loans in the banking system and leverage in the corporate sector were already high; there was a low return on invested capital; capital inflows were biased toward short-term capital and against foreign direct investment; there was a lack of transparency (including on the country's short-term foreign liabilities); and substantial political uncertainty exacerbated the government's credibility problem. ${ }^{15}$ Yes, many of these structural problems were long standing and despite them, Korea had shown impressive growth performance over several decades. And yes, Korea has staged an impressive V-shaped recovery without eliminating all these structural problems. Nevertheless, it does not follow that Korea could have regained market confidence without making a good "start" on structural reform in 1997-98. Fund financing cum debt rescheduling and an (eventual) turn to easier monetary and fiscal policies -- without any structural policy reform -- would not have turned the situation around. Treating only the symptoms and not the (structural) root cause of the problem is not the way to restore confidence. Looking at pre-crisis fiscal positions in the crisis countries without considering the contingent government liabilities associated with financial-sector restructuring provides a misleading picture of fundamentals. ${ }^{16}$ And the alleged negative effect of Fund public pronouncements on market confidence is said to be much exaggerated. Once Thailand's fall "woke up"

\footnotetext{
${ }^{14}$ See Fischer [1999].

15 See Roubini's comments in McHale [2000b]. Claessens et al. [1999] also found that (pre-crisis) the four countries most seriously affected by the Asian crisis ranked low on the quality of the regulatory environment in an international comparison of middle -income emerging economies in East Asia and Latin America.

${ }^{16}$ See Boorman et al. [1999].
} 
market participants to the poor health of banks and corporates in the rest of Asia and every large G-10 bank and security house in the region was issuing weekly reports on the rising share of non-performing loans in Asian financial systems, it is very unlikely that a Fund statement claiming it was only a short-term liquidity crisis would have turned the tide (after all, the Fund's then Managing Director was already telling all who would listen that the crisis was really "a blessing in disguise"). ${ }^{17}$

Reflecting, inter alia, their less preferred access (in terms of maturity, currency, and predictability) to international capital markets, their weaker institutional framework (ranging from judicial systems to insolvency regimes), and their track record of higher political instability, developing countries are different from industrial countries.

Recognizing this difference is not unequal treatment but seeing the world as it is. If the Asian crisis countries -- despite their impressive performance on economic growth, inflation, and macro-fundamentals over a long period -- were regarded by private financial markets as just like industrial countries, they could have "done an Australia" and got out of the crisis by lowering interest rates and letting their exchange rates depreciate moderately -- and this without any Fund assistance. ${ }^{18}$ In the event, they could not do that. Nor will the crisis countries be able to sustain their recoveries if they lapse back into the same structural weaknesses they had before. As such, it is not realistic to expect a developing country that gets into a crisis to live by the same structural policy conditionality as would a troubled industrial country. ${ }^{19}$ For the foreseeable future,

\footnotetext{
${ }^{17}$ See Goldstein [1998] and Ahluwalia [2000] on the "wake up" hypothesis as an explanation of the contagion in the Asian crisis.

${ }^{18}$ See Krugman [1998] on what the "confidence game" means for monetary and fiscal policies in developing countries during a crisis versus what is asked from industrial countries.

${ }^{19}$ See Eichengreen and Hausman [2000] on financing differences between developing countries and industrial countries.
} 
developing countries will have to contend with a history of banking, debt, and currency crises, and restoration of confidence will often require a different dose and mix of macroeconomic and structural policies than would be the case for industrial countries. There is no indication that disagreement over past Fund structural policy conditionality is hampering the work of groups like the G-20 and the FSF; quite the contrary, those groups are making real progress in areas like the application of international financial standards.

The Fund has developed considerable expertise in dealing with banking and financialsector problems in developing countries. Over the past five years, more than 45 specialists (including former bank supervisors) have been added to the staff of the Fund's Monetary and Exchange Affairs Department alone. Admittedly, bank closures in Indonesia did not go well. But since deposit insurance arrangements were not in place, since the authorities were willing to close only a small share of the insolvent banks, and since there were concerns about the moral hazard effects of a blanket guarantee, there was no easy alternative to that action. ${ }^{20}$ Likewise, if stricter bank capitalization requirements had not been instituted in the crisis countries, we would have seen rampant “double or nothing" lending behavior by insolvent lenders and an even higher fiscal bill for the bank clean-up. Evidence on the existence of a credit crunch in the crisis countries in 1997-98 is far from clear cut. ${ }^{21}$

In areas outside the Fund's comparative advantage, the Fund draws heavily on other IFIs with the requisite expertise -- and especially on the World Bank. This collaboration is particularly close on poverty reduction and social safety net issues but also applies increasingly to corporate governance, privatization, trade policy, and environmental

${ }^{20}$ See Lindgren et al. [1999].

${ }^{21}$ See Lane et al. [1999]. 
impacts. Eliminating all overlap between the Fund and the Bank (on fiscal and banking reform) is neither feasible nor desirable. The Fund's major focus in the poor countries remains on the macroeconomic framework -- a specialization which no other IFI is as qualified to handle. A merger of the Fund and the Bank is unappealing -- both because it would sacrifice the speed and efficiency that comes with still a rather small IMF, and because a mega-IFI would have too much power across a wide spectrum of macro and microeconomic issues.

Yes, the Fund has given increased emphasis in recent years to economic growth and to social conditions in the design and implementation of its programs with developing countries -- just as it was responsive to the unique opportunity and massive need for institution building systems in the fledging market economies and new democracies of Eastern Europe. The world has changed. If the Fund did not change with it and if the Fund did not embrace the same objectives in its programs as its members pursue in their national economic policies, there would be little chance that Fund programs would be either agreed or implemented. $^{22}$

Structural policies are not like macroeconomic policies and indicators of policy compliance have to reflect those differences. You can't measure progress on banking supervision or privatization the same way you track net domestic credit or international reserves. Performance benchmarks for structural policies have to be qualitative and a measure of discretion is needed to evaluate the results. Also, because of the interdependencies among structural policies, a macroeconomic impact will come only if progress is made on many fronts simultaneously. Furthermore, the devil is in the details. It makes a big difference if the borrowing country responds to a Fund condition for a 
large cut in the budget deficit by slashing expenditure on health and education versus the curtailment of the national car project. And because both the implementation of and payoff from structural projects take longer than macroeconomic and exchange rate policies, it is necessary to measure progress along the way. All of this produces many detailed structural performance tests and some uncertainty about whether the overall effort will warrant Fund financial support, but there are no shortcuts that would work better.

The rest of the paper elaborates on these issues and sets out some additional arguments and factual material relevant for gauging what IMF structural policy conditionality should be like in the future. In Section II, I ask what if any guidance on structural policy involvement can be gleaned from the Fund's charter and/or guidance notes from its Executive Board. I then discuss three alternative mandates for Fund lending within which structural policy conditionality might operate -- ranging from a narrow one based on correction of balance-of-payments problems and resolution of the current crisis, to broader ones that add avoidance of future crises and pursuit of "high quality" economic growth to the agenda. Section III looks at various dimensions of Fund structural policy involvement and conditionality -- both in the Asian crisis countries over the past three years and more broadly over the past several decades. It also offers some tentative conclusions on the effectiveness of that conditionality, with particular emphasis on the compliance with Fund conditionality. Because very little factual material has been published heretofore on Fund structural policy conditionality, Section III contains a number of tables and charts documenting the patterns in such conditionality. In Section IV, I speculate on why the scope and micro- management of Fund structural policy conditionality have increased in recent years. Section V lays out a set of potential

\footnotetext{
${ }^{22}$ See Camdessus [1999b].
} 
approaches to streamlining Fund structural policy conditionality. Finally, Section VI provides some brief concluding remarks that summarize my own views on Fund structural policy conditionality. A postscript summarizes the findings of a group of very recent Fund reports on conditionality -- including one (IMF [2001c]) with an expanded data base on Fund structural conditions -- that appeared after (the body of ) this paper was written.

\section{STRUCTURAL POLICIES AND THE MANDATE OF THE IMF}

\section{A. Scripture and Field Manuals}

One starting point for figuring out how involved the Fund should be in structural policies would be to look at the Fund's basic marching orders. These range from the IMF's charter (called the "Articles of Agreement") to specific guidance notes issued by the Fund's Executive Board to Fund staff.

Table 1 reproduces (from Article I of the Articles of Agreement) the Fund's purposes. While amendments have been made to other parts of the charter over the past fifty five years, not so with the purposes. Two things are immediately obvious from even a casual reading. There are many purposes --not just one; and there are a number of terms and concepts -- such as "confidence," "national and international prosperity," "temporary," and "exchange system"-- that are (and indeed, have been) susceptible to multiple interpretations.

It is clear (at least to me) that a primary objective is not only to correct balance-ofpayments disequilibria but also to do so in a particular way, that is, in a way that doesn't involve either excessive deflation/unemployment at home or beggar-thy-neighbor 
policies. This is how I interpret the phrases: (in paragraph 5) “.... without resorting to measures destructive of national and international prosperity;" and (in paragraph 3 ) “... to avoid competitive exchange depreciation." Such an interpretation is of course also consistent with the Fund's establishment as a response to the beggar-thy-neighbor and Great Depression problems of the 1920s and 1930s.

There is also clear support for measures that promote openness to international trade and a multilateral system of payments, and opposition to measures that hamper this openness. Capital movements are not mentioned. Again, this is consistent with the perceived (trade/output vicious circle) lessons of the 1920s and 1930s, and with the then popular view about the perils of destabilizing capital flows.

While there is no denying that a key task of the Fund at the time of its creation was to oversee a system of fixed but adjustable exchange rates, I interpret the promotion of "exchange stability" (in paragraph 3) as going beyond any particular form of exchange arrangements (be it adjustable pegs, currency boards, floating rates, etc). Put another way, I don't see the raison d'être of the Fund as having disappeared in the early 1970s along with the arrival of floating exchange rates. If the intention were otherwise, paragraph 3 would presumably have referred to "exchange rate" stability, and there would be no purposes other than that one.

Although Article I makes it plain that the framers regarded “... high levels of employment and income" and "...development of productive resources" as good things, it doesn't say that the Fund should pursue those objectives by whatever means available. Instead, they specify that the Fund should facilitate “... the expansion and balanced 
growth of international trade" and "contribute thereby" to buoyant domestic economic activity.

Where else might one look in the Fund's charter for advice relevant to structural policy conditionality? Many would say the revised (in 1976) Article IV, which deals with general obligations of member countries and with the Fund's surveillance responsibilities. Here, economic growth, and to a lesser extent, international capital movements, get greater play (than in the Fund's purposes). Specifically, the new Article IV recognizes specifically that the essential purpose of the international monetary system is to provide a framework that both "... facilitates the exchange of goods, services, and

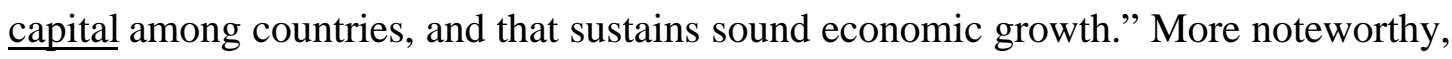
member countries assume the general obligation to "... endeavor to direct ... economic and financial policies toward the objective of fostering orderly economic growth with reasonable price stability," and the Fund assumes the obligation to oversee the "compliance" of each member country with this obligation.

Since "economic and financial policies" directed toward orderly economic growth potentially covers a lot of ground, the practical upshot of the revised Article IV was that it gave the Fund a much broader license to conduct wide-ranging surveillance and annual consultations with members. Ever since then, the Fund's Article IV consultation reports have covered a host of policy areas, including many that would be designated as structural policies. ${ }^{23}$ Even though Article IV carries the title, "Obligations Regarding Exchange Arrangements," it embodied the view that you had to look at the underlying domestic policy determinants of a stable exchange rate system to see if countries were

\footnotetext{
${ }^{23}$ For a review and analysis of the content of Fund surveillance, see Crow et al. [1999].
} 
meeting their international obligations. ${ }^{24}$ Yes, Article IV is about Fund surveillance -- not about Fund policy conditionality. But the fact that the former has been given much wider scope (since at least the mid-1970s) probably has contributed somewhat to a wider field of view in Fund lending arrangements as well (more on that in Section IV).

But what about more specific directives relating to performance criteria agreed and issued by the Fund's Executive Board. In my view, the most relevant document is probably the conditionality guidelines for stand-by arrangements, issued in 1979; see Table 2. To make a long story short, while the guidelines permits the number and content of performance criteria to vary with a country's problems and institutional arrangements, guideline 9 specifies, inter alia, that performance criteria will “...normally be confined to macroeconomic variables," and that "performance criteria may relate to other variables only in exceptional cases when they are essential for the effectiveness of the member's program because of their macroeconomic impact." My interpretation of all this is that, at least in Fund standby arrangements, the intention was to limit the number of structuralpolicy performance criteria and to avoid "micro" conditionality (that is, measures that don't have macroeconomic impact). While these guidelines have been revisited many times during later Board reviews of conditionality, they have been repeatedly endorsed.

But one must also take note that a variety of other lending arrangements (besides standbys) has been created in the Fund with the support of the membership over the past thirty years (ranging from a facility to assist transition economies cope with the shift away from state trading to multilateral market-based trading, to one that was to assist countries experiencing liquidity problems related to $\mathrm{Y} 2 \mathrm{~K}$ ). More to the point of this

\footnotetext{
${ }^{24}$ Eichengreen [1999] has made a similar argument that the Fund can't expect to be successful at promoting international financial stability without addressing sources of financial instability at the national level.
} 
paper, some of those lending windows are directly aimed at protracted balance-ofpayments problems and at supporting comprehensive efforts at macroeconomic and structural reform. These include the Extended Fund Facility (EFF, established in 1974), and both the Structural Adjustment Facility (SAF, established in 1986) and Enhanced Structural Adjustment Facility (ESAF, established in 1987); eligibility for both the SAF and the ESAF is restricted to low-income countries. ${ }^{25}$ For these lending windows, structural policy involvement is at the heart of the exercise and there is little guidance on how many or what kinds of structural policy measures would be viewed as "out of bounds."

Given the prominence of governance issues in the Asian crisis, a final guidance note worth noting is the one issued in July 1997 by the Fund's Executive Board on "The Role of the IMF in Governance Issues." While the note states right at the beginning that “... the responsibility for governance issues lies first and foremost with the national authorities..," it seems to give the Fund staff quite wide berth to include governance and corruption measures in Fund conditionality if they can make the case that governance problems have some direct macroeconomic impact. In addition, while the note urges the Fund staff to rely on other institutions' expertise in areas of their purview, it states that the Fund could nevertheless recommend conditionality in those areas (outside the Fund's expertise) if the staff considered that such measures were ".... critical to the successful implementation of the program." Given the timing and context of this guidance note (just at the outset of the Asian crisis), some Fund staff have expressed the view (to me) that the Fund's Board was sending them a signal that they would henceforth not support programs that ignored serious and widespread governance and corruption problems.

\footnotetext{
${ }^{25}$ In 1999, the ESAF was reorganized into the Poverty Reduction and Growth Facility (PRGF).
} 
To sum up, the Fund's existing marching orders on structural policy conditionality are $\underline{\text { Janus-faced enough so that both supporters of narrow conditionality and those of more }}$ comprehensive conditionality can find their own biblical passages to buttress their arguments. On the one side, I don't see in the Fund's charter a broad agenda aimed at high quality growth. What I see instead is a focus on balance-of-payments adjustment, trade opening, elimination of payments restrictions, efforts to increase stability of the exchange rate system, and a directive to avoid modes of external adjustment that make recession/deflation deeper than necessary and that impose undue costs on other countries. ${ }^{26}$ This is not to deny that the Fund's membership may want to pursue highquality growth (and poverty reduction) for a variety of reasons, including moral imperatives. It's just that I can't find that commandment on the original stone tablets. In a similar vein, the Fund's conditionality guidelines for standby arrangements appear to have had the intention of limiting the number of structural performance criteria, particularly if they are micro in nature. On the other side of the ledger, the Fund's overall surveillance responsibilities (under the revised Article IV) are quite wide ranging as regards structural policies, a succession of specific lending windows has been established over the past 25 years or so with an explicit structural policy orientation, and guidance notes on "new" structural policy issues like governance and corruption give the Fund staff considerable leeway to include such measures in conditionality so long as they can make a case that they are critical to the success of the program. Perhaps more telling, I could find no evidence of concern about the scope or intrusiveness of structural policy conditionality in the published summaries (so-called Public Information Notices, or

\footnotetext{
${ }^{26}$ It's also relevant to note that, unlike the charter of the EBRD, the Fund's charter says nothing about promoting "democracy;" see Polak [1991] for a discussion of political influences on Fund lending.
} 
PINs) of Executive Board meetings on the Thai, Indonesian, and Korean programs over the past three years -- even though the number and detail of structural conditions in those three programs are extraordinary (see Section III below).

\section{B. Three Alternative Mandates}

If there is relatively little guidance available about the appropriate intrusiveness of Fund structural policy conditionality from official sources, one might consider what different mandates for the Fund would imply about such conditionality. Here, I consider three possibilities, starting with the narrowest and ending with the broadest (and most ambitious).

(a) Mandate I: the Fund's primary focus would be on macroeconomic and financial stability; its crisis management guideline would be to assist a country to get out of the current crisis as soon as possible (without imposing undue costs on itself or its neighbors).

An announced IMF focus on macroeconomic and financial stability would be similar to the increasing popular practice of national central bank announcing that their primary objective is price stability. It doesn't preclude giving some consideration to other objectives but it makes clear which objective is king and where the authority's central responsibility lies. The emphasis on getting out of the current crisis would mean that crisis management/resolution -- and not crisis prevention -- should guide program design. Crisis-prevention measures would presumably then be handled by the country on its own after the current crisis is resolved. 
Would Mandate I preclude Fund structural policy conditionality during a crisis? The answer, I believe, is no. But the extent of the structural conditions would be limited to measures directly related to resolution of the current crisis and their form would depend both on the nature of the crisis and the institutional structure in place in the crisis country; in addition, the design of essential structural policy conditions outside the Fund's core competence (monetary, fiscal, exchange rate, and financial sector policies) would need to be handled by other IFIs. A few examples should suffice to illustrate the point.

Suppose that key contributory factors to a balance-of-payments crisis were an overvalued exchange rate and overly expansionary monetary and fiscal policies. Also assume that correction of relative prices was being thwarted by widespread indexation agreements in wage contracts. Assume that the alternatives to devaluation as an adjustment tool are a more draconian tightening of monetary or fiscal policy (that would drive the domestic economy into deep recession) and/or a large hike in tariff and nontariff barriers. In that case, reduction or elimination of those indexation provisions could be regarded as "essential" to external adjustment (without either excessive deflation or beggar-thy-neighbor effects ) and a labor-market performance test could be part of conditionality. ${ }^{27}$

Next consider a case where the primary source of the external disequilibrium is a large budget deficit. Assume that the necessary fiscal adjustment needs to be large, that the economy is expected to undergo a serious contraction, that the incumbent government is quite unpopular at home (because there is a long history of cronyism and corruption), and that there is no social safety net to speak of. In that situation, it could be argued that the 
Fund program needs to contain a few structural measures (e.g., the closing of a government cartel or monopoly) to send a visible signal to the public that some patronage is being taken away from well-connected government cronies and therefore that the program will be "even-handed" -- and this even if the structural measures themselves have no macroecono mic impact and lie outside the Fund's core competence. ${ }^{28}$ Here, these structural measures might be defended as necessary to establish "confidence." Similarly, the creation of an unemployment insurance scheme or some other form of social safety net could be viewed as necessary to sustain popular support for the fiscal correction effort over the one or two-year program period.

Next, picture a situation where there is a banking crisis underway without a deposit insurance system in place. Depositors are withdrawing deposits from a group of weak banks and the government is supporting the weak banks' ability to meet withdrawals by providing liquidity assistance to those banks. The deposit run is spreading and the liquidity injections are pumping up the monetary aggregates and driving down the exchange rate. It is also known that substantial funds will soon be needed to recapitalize insolvent banks and to increase capital at solvent but still weak banks. Because its debt burden is already high, the government cannot fund all the bank clean- up costs on its own. It will need help from private creditors abroad. Here too, one could defend structural conditions relating to bank closures and/or to deposit insurance reform as essential for resolving the current crisis; without them, the authorities will not be able to

\footnotetext{
27 Another example where labor market policies could be considered essential to overcoming the current crisis is when a banking crisis cannot be overcome without financialsector and corporate restructuring, and the latter cannot be accomplished without revision of restrictive laws governing employee layoffs.

${ }^{28}$ Allen [1993, p. 18] takes such a view: "Structural policies can also help build and maintain the political consensus that will support macroeconomic stabilization -- for example, by combating unproductive and politically unpopular rent-seeking activities."
} 
control monetary policy and to halt the free fall of the currency. If the immediate aim of raising funds from abroad is being hampered by restrictions on capital inflows and/or by poor disclosure that prevents foreign creditors from judging the worth of domestic banks, removal/correction of restrictions/disclosure practices too might be defended as legitimate elements in conditionality.

In contrast to the above scenarios, consider a crisis situation brought on say, by a large terms-of-trade shock or a shift in investor sentiment stemming from contagion in a neighboring country. Assume also that there are many structural policy weaknesses and institutional gaps but that these are not serious enough or linked closely enough to monetary, fiscal, and exchange rate policies to prevent the crisis from being resolved with traditional macroeconomic instruments plus some Fund financing. Here, however desirable structural measures may be for longer-term performance, they would not be included as conditions for the program. A plain vanilla Fund program will do the job. Another relevant question is whether Mandate I would still permit the Fund to make a contribution to poverty reduction in poor countries. The answer is yes, but only in so far as macroeconomic and financial stability itself contributes to poverty reduction, or because the Fund (in collaboration with the Bank) sees the incorporation of social safety nets into crisis resolution programs as necessary for the successful implementation of those programs. Longer-term efforts (outside of crises) to fight poverty would then be handled by the Bank and the regional development banks.

(b) Mandate II: the Fund's primary focus would be (as in I) on macroeconomic and financial stability: its crisis guideline would be to assist a country not only to get out of the current crisis but to minimize the chances of getting into another one down the road. 
While the Fund's core competence remains the same in Mandate II as in I, the big difference is that the Fund now incorporates crisis prevention as well as crisis resolution in program design. An implicit judgement here is that the country needs to use the crisis as a mechanism to reduce its crisis vulnerability and that it would not be able to do this on its own (i.e., without a Fund program) after the current crisis is resolved. Better then to "make hay while the sun shines" and combine crisis resolution and crisis prevention in the current program. If confidence in the crisis economy is very low, the Fund might also argue that investors will not return unless there is evidence that the probability of another (near-term) crisis is low; this in turn requires proof that the old (crisis-prone) "system" is changing and structural reform would be part and parcel of such proof.

Mandate II increases substantially the scope for structural policy conditionality -- even without going into non-core areas of economic policy. Again, a few examples convey the flavor.

Assume that the country has a long-standing problem of undisciplined monetary policy and that monetary policy excesses are also a key factor in the current crisis. In that case, the Fund might argue that a performance criterion that simply says that monetary policy will be tightened within the existing regime will not be credible. In this situation, the program might contain structural policy conditionality that either specifies granting independence to the central bank or that takes the monetary reins out of the central bank's hands by establishing a currency board or single currency.

One could tell a similar story about long-standing weaknesses in fiscal policy that lead a country to accumulate a very heavy external debt burden. When say, a large, negative shock occurs to the terms of trade (e.g., oil prices fall), foreign investors run for the exits 
and a debt crisis breaks out. Assume that the chronically weak fiscal position owes much to a narrow tax base, to a host of large loss-making public enterprises, and to the absence of a proper expenditure-control and budgeting departments in the Ministry of Finance. In parallel with the immediately-preceding example, the Fund might argue that a performance criterion that simply targets a lower fiscal deficit for the next year will not be credible. As such, the Fund program could contain structural conditions for widening the tax base, for privatizing state enterprises, and for establishing new administrative units in the Ministry of Finance.

Carrying forward the same theme, imagine a banking crisis whose proximate determinants are a sharp contraction of economic activity and/or a sharp rise in interest rates connected with a defense of a fixed exchange rate. But assume also that there was a large backlog of non-performing loans brought on by: state-owned banks that lent without any regard to creditworthiness of borrowers; commercial banks that had long demonstrated a proclivity toward "connected lending;" lax loan classification procedures that encouraged the "evergreening" of bad loans and that grossly overstated the true value of bank capital; a legal framework that made it difficult for banks to seize collateral from bankrupt borrowers; lack of effective banking supervision from a bank supervisory agency that had neither the political independence nor the mandate or resources to do its job; and lender moral hazard, stoked by repeated episodes of bailing out bank depositors and creditors. Against such a background, the Fund might maintain that a program that merely specified closing insolvent banks and recapitalizing others to international standards would amount to flushing money down the drain. Even if the the current banking crisis were resolved, it wouldn't be long before the same underlying 
vulnerabilities produced a repetition (thereby exacerbating the problem of "prolonged use" of Fund resources). Better then -- so the argument would go -- to require structural policy conditions that would change each of these poor banking and supervisory practices.

The same kind of argument could be made about the need for conditions (on bank bailouts and the like) to control "moral hazard" problems, which, by definition, relate to the effect of inappropriately-priced insurance arrangements (extended this period) on the risk-taking behavior of policyholders next period. Put in other words, it is precisely the worry about avoiding the next crisis that makes it necessary to put additional conditions on how you manage the current crisis.

(c) Mandate III: the Fund's focus would be on macroeconomic and financial stability and on sustainable growth; its crisis guideline would be to assist the country not only to get out of the current crisis and to reduce its crisis vulnerability but also to put in place the conditions for sustainable high-quality growth. The difference here with respect to Mandates I and II is that "high quality" growth now occupies a more central role both in the Fund's overall mandate and in its crisis-fighting strategy. Under this more holistic approach, conditionality would likely encompass measures that are viewed as necessary to improve economic growth and protect the poor and the vulnerable, as well as measures to improve the country's resilience to future crises. A hypothetical country scenario can again help to illustrate the differences involved.

Consider a country that is suffering from persistently weak economic growth, a chronic budget deficit, a weak external position, pervasive state intervention, heavy public ownership, protectionism, and a host of governance and corruption problems. A large, 
negative terms-of-trade shock and/or a group of bank failures may have pushed this country into crisis but for the last decade or more it may never have been very far away from crisis.

Reflecting the focus on economic growth (under Mandate III), the Fund and the country authorities might agree that the program ought to have a three year rather than a one year tenure, so that any aggregate demand reductions could be made more gradual and so that there would be more time for structural reform to take hold. In addition, the Fund might ask that the country only make good progress toward external payments viability during the program period rather than to actually achieve such viability. In an effort to reduce distortions that create an anti-export bias and that hamper efficient resource allocation, the program might well call for: scaling-back the extent of price controls and state intervention in marketing of exports, foodstuffs, fertilizer, and petroleum products; reduction/elimination of surrender requirements and controls on foreign exchange allocation; reduced reliance on quantitative restrictions on imports and a reduction in the level and dispersion of tariff rates; privatization of selected public enterprises and the entering into "performance contracts" with existing managers of public enterprises; liberalization of interest rates (and other measures to move from state to market allocation of credit); development of financial markets for inter-bank funds, government securities, and stocks; and the phasing-out of government-owned banks.

To protect the most vulnerable groups, such a program would probably also place conditions on the composition of government expenditure cuts, as well as an overall target for the budget deficit. Specifically, these structural conditions could call, inter alia, for a shift in government expenditure away from military and "showcase" expenditures 
toward expenditure on primary education and health care; severance pay and retraining for workers released from public enterprises that are being privatized; a gradual (rather than abrupt) reduction of price controls on commodities that loom large in poor people's budgets; and the creation of an unemployment insurance system. There might likewise be provisions for special credit arrangements for agricultural producers and for small and medium-sized businesses, and the differential impact of currency devaluation on urban consumers versus agricultural exporters might be subject to partial compensation. As part of efforts to combat corruption problems, audits and public disclosure of findings might be required of certain financial institutions and/or of government-sponsored monopolies, and employment practices in the civil service could be subject to review. And core labor standards might be put forward if there were strong evidence of significant departures from them.

To sum up, what gets included in Fund structural policy conditionality depends in good measure on the nature of the crisis and on the extent of interdependence between traditional Fund macroeconomic policy instruments and structural policies. But the intrusiveness of conditionality also depends on how broad are the objectives of the Fund and the country authorities. Trying to get out of the current crisis is one thing. Trying to ward off a future crisis is quite another. And trying to spur high-quality growth in a lowincome country with a host of government-induced distortions and large institutional gaps is something else again. Yet another relevant factor, particularly as regards the intensity or degree of detail in Fund conditionality, is how much confidence the Fund and creditor governments have in the willingness of the crisis country to carry through on its policy commitments; the greater the skepticism on that score, the greater are likely to be 
the number of prior actions and other performance tests included in programs. But that takes us into the next section.

\section{THE STRUCTURAL CONTENT OF FUND POLICY CONDITIONALITY AND ITS EFFECTIVENESS}

Thus far, I have summarized arguments about Fund structural policy conditionality and discussed how the Fund's mandate might affect the scope and details of such conditionality. But I have not discussed the available facts on Fund structural policy conditionality, nor the existing literature on the effectiveness of conditionality. That is the subject of this section. First, I ask how commonplace, wide-ranging, and detailed structural policy conditions have been in Fund programs; whether structural policy conditionality seems to be increasing over time; in what policy areas structural conditionality has been most intensive; and what performance tests have been used to monitor this conditionality. Second, I then ask what we know about the effectiveness of that structural policy conditionality, including the track record on compliance with Fund conditionality. Most of these questions are not entirely straightforward to answer -- both because the relevant data are available only in pieces, and because the "counterfactual" to Fund policy conditionality (that is, what would happen in the absence of a Fund program) is extremely difficult to know or to estimate.

\section{A. Structural Policies in Fund Programs}

Since there is no comprehe nsive index of Fund structural policy conditionality that is available over a long time period, one has to rely on a set of statistics to tell the story. ${ }^{29}$ In

\footnotetext{
${ }^{29}$ In the Postscript to this paper, I discuss several very recent IMF studies on conditionality (IMF [2001) that trace the evolution of Fund structural conditionality since the mid-1980s; one of these studies
} 
what follows, I review, in turn: (i) data on the number of total structural policy conditions per program year for a sample of 20 Standby arrangements (SBAs) and 12 Extended Fund arrangements (EFFs) for the 1996-99 period; (ii) data on the average number of structural performance criteria for all Fund programs over the 1993-99 period; (iii) data on the number of structural policy conditions (overwhelmingly structural benchmarks) in recent (1997-2000) Fund programs with three Asian crisis countries (Indonesia, South Korea, and Thailand); (iv) data on the average number of structural benchmarks per Fund program for 33 transition economies over the 1993-99 period; and (v) data on the number of structural benchmarks in earlier SAF programs. For each body of data, I am interested not only in the scope and intensity of structural policy conditionality, but also in the trend, the differences across different types of Fund programs (SBAs, EFFs, and SAF/ESAF/PRGF programs), and the distribution across structural policy areas.

Before getting to all that, a brief digression on the instruments that the Fund uses to monitor compliance with conditionality is warranted. For the purposes of this paper, four of these are of interest.

$\underline{\text { Performance criteria }}$ (PCs) are meant to provide a direct link between program implementation and disbursement of Fund resources. If the criterion is met on the agreed test date (typically set at quarterly intervals), the member country is assured of disbursement; if the criterion is not met, the country cannot draw unless a "waiver" is obtained. Waivers are granted when a country's noncompliance with performance criteria is viewed by the Fund as inconsequential or when it reflects significant exogenous 
developments not foreseen at the time the program was framed. ${ }^{30}$ PCs are expected to be under the control of the borrower, capable of being precisely and objectively formulated and monitored, and subject to relatively short (usually less than 45 days) reporting lags. In the structural area, a PC could, for example, specify that elimination of restriction $\mathrm{x}$ on current payments be accomplished by date $\mathrm{y}$, or that three insolvent finance companies be closed by date $\mathrm{z}$. Prior actions are policy measures that the country agrees to take before a Fund agreement goes into effect. They are apt to be employed when severe imbalances exist and the country is viewed as having had a poor track record of implementation (in earlier Fund programs). Structural benchmarks (SBMs) are indicators which aim to delineate the expected path of reform for individual structural policy measures and that can facilitate the evaluation of progress for these actions. Because many structural policies cannot be expressed in quantitative form, structural benchmarks are usually expressed qualitatively; for example, if the program calls for privatization of the stateowned telephone company, submitting the privatization bill to the legislature by date $\mathrm{x}$ could be one structural benchmark. Failure to meet structural benchmarks conveys a negative signal but does not automatically render a country ineligible to draw; instead, a decision about eligibility would be judgmental and would likely be taken in a broader mid-year program review --itself an instrument of conditionality -- with an eye toward the country's overall progress on the structural front. Program reviews, like SBMs, assess implementation of policies not amenable to monitoring via PCs (because of their

\footnotetext{
${ }^{30}$ Waivers also require that the authorities have taken the necessary action to bring the program back on track if this is necessary to meet its objectives.
} 
imprecise or qualitative nature). Reviews are broader than individual SBMs and can be used, for example, to assess whether there needs to be a change in program design. ${ }^{31}$

(i) Number of (total) structural policy conditions per program year -- At this point, the most comprehensive measure of Fund structural policy conditionality is that produced by the Fund itself via its so-called MONA database (which stands for Monitoring Fund arrangements). It is the only series available that combines information on all four types of structural conditions, namely, performance criteria, structural benchmarks, prior actions, and conditions for completion of program reviews. When only one of those structural policy conditions is used, there is a danger that you are seeing only one part of the elephant. The Fund's index of programmed structural policy measures is then divided by the length of the period to obtain figures on number of programmed structural policy measures per annum. The rub is that this comprehensive measure is available only for the 20 Standby arrangements (SBAs) and 12 Extended Fund arrangements (EFFs) over the 1996-99 period. $^{32}$ To my knowledge, this comprehensive measure of Fund structural policy conditions has not been published before.

Table 3 presents the goods. Three conclusions stand out. First, the number of $\underline{\text { structural }}$ policy conditions that would be typical for say, a three-year EFF Fund program over the last few years is high; specifically, it would be more than fifty (3 times the annual average of 18 measures per annum). ${ }^{33}$ For a typical one-year SBA, it would be somewhere between 9 and 15 (depending on whether we used the median or the mean).

\footnotetext{
${ }^{31}$ When conditionality includes a program review, the text of the arrangement specifies what elements are to be reviewed; the review also assesses whether or not the program's objectives are in jeopardy.

${ }^{32}$ See the Postscript for a summary of data going back to 1989.

${ }^{33}$ Because the data in Table 3 are expressed as the number of conditions per annum rather than per program, I need to assume that the number of conditions varies proportionally with time to arrive at conclusions about the number in conditions in a "typical" three-year program.
} 
This is a far cry from the "only in exceptional cases" guideline called for in the (1979) conditionality guidelines (for SBAs). Second, the median number of structural policy conditions is much higher (double) for EFFs than for SBAs. This is not surprising. As noted earlier, EFFs must have a structural policy orientation; SBAs may have structural conditionality too but don't necessarily have to (if structural problems are not viewed as serious or pressing). Note that the difference between SBAs and EFFs vanishes when one looks at the mean number of conditions -- a finding that could well reflect the presence of a few SBAs with very high structural policy content. And third, there is quite a lot of variation across both SBAs and EFFs in the extent of structural policy conditionality. Since these data are thus far available only for the 1996-99 period as a whole, there is nothing that can be said here about trends.

The Fund has broken down its comprehensive measure of structural policy conditions into ten broad policy areas. The results are portrayed in Figure 1. In short, what we see there is that about two-thirds of structural policy conditions are concentrated in three areas: financial-sector policies, tax and expenditure reforms, and public enterprises and privatizations. Since the Fund's core competence is often identified to be monetary, fiscal, exchange rate, and financial-sector policies (see, for example, the Council on Foreign Relations [1999]), this would seem to belie the charge that, on average, most of the Fund's focus in structural policies is far afield from its main expertise -- or to put it in other words, that Fund structural policy conditionality is typically a "mile wide and an inch thick." At the same time, Figure 1 does show that Fund structural policy conditionality has reached into a number of "non-core" structural policy areas (e.g., labor markets, social safety nets). 
(ii) Average number of structural performance criteria per program-- The Fund's

MONA database also contains information on performance criteria (PCs) for the longer 1993-99 period. Tables 4, 5, and 6 below present the average number of performance criteria per program for all Fund programs, for ESAF/PRGF programs, and for SBA and EFF programs, respectively; separate figures are also given for the transition economies and (in Table 4) for the Asian economies. In these tables, "quantitative performance criteria" refer to macroeconomic variables (e.g., the nominal value of the fiscal deficit, net domestic credit of the central bank, the stock of net international reserves, etc) that are used to track compliance with monetary, fiscal, exchange rate, and external debt policies. "Structural performance criteria" are the ones meant to assess compliance with important structural policy commitments. Note that the data here are calculated per program -- not per program year. This is more informative in some respects but also carries the disadvantage that the annual figures can be biased upward (downward) if there are more (less) multi-year arrangements agreed in a given year. Note also that because we are dealing only with one component of structural policy conditionality in Tables 4-6, we have to be careful about generalizing about the overall intrusiveness of Fund structural policy conditionality from these figures.

Five main conclusions emerge from Tables 4-6. One is that "structural" PCs are on average less numerous than for quantitative macroeconomic PCs -- with the notable exception of the three programs for the Asian crisis economies in 1997 (see the upper two panels of Table 5 versus the lower one). A second conclusion is that the number of structural PCs in the programs with the three Asian crisis economies in 1997 (an average of 14 per program) was way above (roughly four times) both the average for all Fund 
programs over the 1993-99 period (an average of 3.3 per program) and for 1997 alone (an average of 7 per program); in contrast, the average number of quantitative macroeconomic PCs was actually lower in the Asian economies than for all Fund programs. Finding number three is that the average number of structural PCs in programs with the transition economies was below (not above) the average for all Fund programs over this period. And fourth, there have on average been more structural PCs in ESAF/PRGF programs than in SBA and EFF arrangements (taken together).

A fifth finding -- at least for all Fund arrangements taken together -- is that we do observe some upward trend in the average number of structural PCs as we move from the earlier part of the period ( 2 in 1993-95) to the latter part $(3.3,1996$ and 98-99) -- and this even if we exclude 1997; that being said, the straw that stirs the drink in the average PC numbers is clearly the high figure (14 per program) for the three programs with Asian crisis countries in 1997.

Unfortunately, there are no directly comparable statistics on average number of structural PCs for earlier periods. ${ }^{34}$ An (unpublished) IMF [1987a] study on SBAs and EFFs during the 1979-87 period does show the breakdown of structural PCs by policy area; if I make the (risky) assumption that there was only one PC per policy area indicated for each country, I get an estimate of 1.3 structural PCs per program for that period -- about a third of the average figure (3.3) for 1993-99 (from Table 4). Polak [1991] reports the average number of total PCs (presumably, quantitative macroeconomic PCs plus structural PCs) per program for some earlier periods. Specifically, his figures

\footnotetext{
${ }^{34}$ But see the summary in the Postscript which points to a trend increase in the number of structural performance criteria during the 1989-99 period.
} 
are less than 6 per arrangement for 1968-77, 7 in 1974-84, and 9.5 in $1984-87 .{ }^{35}$ The comparable figure taken from Table 4 for average (total) PCs per program over 1993-99 would be 11.7. If other monitoring components of Fund policy conditionality (prior actions, SBMs, conditions for program reviews) moved in the same direction over this period -- and Polak [1991] suggests they have -- this would point to a significant increase in the monitoring of Fund conditionality over the past thirty years or so.

As regards the distribution of structural PCs across policy areas for earlier periods, that same 1987 IMF study found that the leading categories were the exchange system (12 percent) and the trade system (6 percent). The financial sector, which led the parade in Figure 1, was in third place in 1979-87 and fiscal policy was yet further behind.

(iii) Number of structural policy conditions in recent Fund programs with Indonesia,

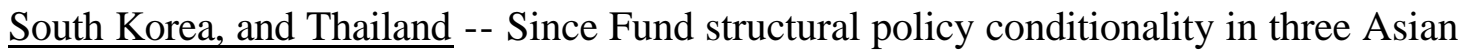
crisis countries has had a lot to do with reopening the debate on the appropriate scope and detail of conditionality, it makes sense to give those programs a separate look. In Table 7, I provide a running count of the number of structural policy conditions --believed to be overwhelmingly made up of conditions for program reviews and structural benchmarks -contained in successive revisions of the Indonesian, Korean, and Thai programs over the 1997-2000 period. In figure 2, I present a rough breakdown of the three crisis programs by structural policy areas. In an effort to convey the flavor of the detail in those programs, I have also reproduced in Table 8 the first half of the full SBM matrix for Indonesia as of June 1998. Perhaps hinting at one of the main conclusions, it was not practical to attach the full list of structural policy conditions for all three programs: as a

\footnotetext{
${ }^{35}$ Kapur [2000] reaches similar findings (to Polak [1991]) on the average number of performance criteria in the 1970s and 1980s. He, however, also cites a figure of 23 (using a somewhat different sample of
} 
group, they are much too long for a paper of this length. As a note of caution, counting the number of structural policy commitments says nothing about which conditions are more important or are more intrusive. Nor does such a count tell us which commitments came at the initiative of the country authorities and which came from the Fund. ${ }^{36}$ And such a count mixes together what you might call formal conditionality (monitored by specific performance criteria and structural benchmarks) and informal conditionality (monitored by program reviews).

The tale told by Table 7 and by Figure 2 can be summarized as follows. First, the number of structural policy conditions included in these programs with the three Asian crisis economies is very large (if not totally unprecedented) -- many more than you can count using all your fingers and toes. ${ }^{37}$ Without claiming any precision, my head count from publicly-available documents is that these structural policy commitments summed -at their peak -- to about 140 in Indonesia, over 90 in Korea, and over 70 in Thailand. Each of these totals is considerably above the average of about 50-plus for all Fund programs over the 1996-99 period. Second, in the programs with Korea and Thailand, the number of structural policy conditions was considerably smaller at the beginning of the program than at its peak -- perhaps because the country authorities and the Fund first laid out the main elements of the structural reform package and then filled in the details as they went along, and because implementation of reforms was pretty good (see discussion below). In contrast, the number of structural policy conditions in the Fund program with

\footnotetext{
programs) for the single year 1999.

${ }^{36}$ Fund staff note that country authorities often use an IMF letter of intent to underline or to "advertise" policy reforms that have recently been made and those that are expected to be made in the near future -even if those reforms are predominantly "home grown;" see the discus sion on this point in the Postscript.

${ }^{37}$ I hesitate to call the total number of structural policy conditions in even the Indonesian program "unprecedented" because I am told informally that there was a larger figure (close to 200) in one of Russia's programs with the Fund.
} 
Indonesia hits its peak pretty early on and then declines as the program period goes on -perhaps reflecting an initial effort to impress the markets with the extent of intended structural reform and then scaling that back as market reaction proved disappointing and as evidence accumulated that implementation capacity/willingness would be lower than anticipated. Third, while financial-sector restructuring and supervision is the dominant policy concentration in all three programs, additional data indicate that the scope of structural policy cond itionality is much narrower in the Korean and Thai programs than in the Indonesian one. Putting aside the financial sector, Thai structural policies are mainly focused on tax and expenditure reform and on corporate debt restructuring. In Korea, the non-financial areas getting most attention are corporate governance and restructuring (and some trade and capitalaccount liberalization). In Indonesia, structural reforms outside the financial sector are more of a mixed bag, with significant commitment clusters appearing for privatization and reform of public enterprises, for trade systems, for pricing and marketing policies, for corporate restructuring, and for tax and expenditure reform; there are also minor clusters for energy and environmental policies and for social safety nets.

Turning to Table 8 , what is striking is the number, scope, and detail of the structural policy commitments made by Indonesia -- including in non-traditional areas of conditionality. There are, inter alia, measures dealing with reforestation programs; the phasing-out of local content programs for motor vehicles; discontinuation of support for a particular aircraft project and of special privileges granted to the National Car; abolition of the compulsory 2 percent after-tax contribution to charity foundations; appointment of high- level advisors for monetary policy; development of rules for the Jakarta Clearing 
House; the end of restrictive marketing agreements for cement, paper, and plywood; the elimination of the Clove Marketing Board; the termination of requirements on farmers for the forced planting of sugar cane; the introduction of a micro credit scheme to assist small businesses, and the raising of stumpage fees. Enough to say that the great bulk of such measures were not included because of their macroeconomic impact; they were presumably included instead for anti-corruption reasons, to instill "confidence" in private investors that the system was changing, to facilitate monitoring of commitments, and (for some commitments) to reflect the structural policy agendas of either other IFIs (the World Bank and the Asian Development Bank) or certain creditor countries (see discussion in Section IV). ${ }^{38}$

(iv) Number of structural benchmarks in Fund programs with the transition economies - Mercer-Blackman and Unigovskaya [2000] have analyzed the use of SBMs in Fund programs for 25 transition economies over the 1989-97 period. Their tally, also derived from the Fund's MONA database, is presented in Table 9. Three observations merit explicit mention.

First, the average number of SBMs per program is roughly twice as high in ESAF (26) and EFF (23) arrangements and as it is for stand-by arrangements (13). Second, although the data in Table 9 are not directly comparable with those in Table 3 (not only are the time periods different, but the latter include all structural conditions while the former include only SBMs), the number of SBMs in standby arrangements for the transition economies do not seem too far out of line with the recent averages for SBAs in all Fund programs -- and they appear to be much lower than the averages on SBMs in the three Asian crisis economies. And third, there is more variation for SBAs in the number of

\footnotetext{
${ }^{38}$ Haggard [2000] shares this view.
} 
SBMs (ranging from one in Bulgaria and Latvia to 35 in Armenia) than for either ESAF or EFF arrangements.

Figure 3, taken from Christiansen and Richter [1999], gives the breakdown by policy area of structural policy conditions for the Fund's programs with the transition economies. ${ }^{39}$ The main message is that the most frequently occurring structural conditions were in the area of public-sector management (institutional reform, tax and revenue policy, expenditure policy, and public wages and employment). Next in line were restructuring and privatizations, and financialsector reforms. After that, you see a fairly even distribution across the remaining areas (energy sector, social safety net, agricultural sector, trade regime, exchange system, etc). The top three categories accounted together for over two-thirds of structural conditions.

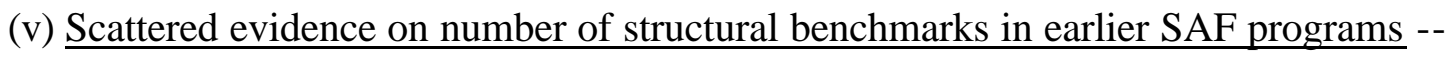
An unpublished IMF study [1987] of 17 SAF arrangements (for low-income countries) in 1986-87 also looked at the number and distribution of structural benchmarks. The main findings were that the average number of SBMs per SAF arrangement was about 7, that there was considerable variation around this average across programs (ranging from 3 in the program for Bolivia to 15 for Uganda), and that structural conditions also ranged quite widely across policy areas (covering the exchange system, trade liberalization and tariff reform, public enterprises, tax and expenditure policy, producer pricing and agricultural marketing, and public sector investment programs).

\footnotetext{
${ }^{39}$ The data used to construct Figure 3 are different from that used in Table 10. The former cover (I think) all structural policy conditions (not just SBMs) and they also cover the Fund's initial programs with the transition economies under the (lower-conditionality) Systemic Transformation Facility. These differences, however are not important for our purposes.
} 
$\underline{\text { To sum up, structural policy conditionality is now a common and important element of }}$ Fund conditionality. When you combine prior actions, performance criteria, structural benchmarks, and conditions for program reviews, it has been typical (over the past few years) for a one-year standby arrangement to have on the order of say, a dozen structural conditions and for a three-year EFF arrangement to have say, 50 of them. About twothirds of those structural conditions are apt to fall in the areas of fiscal policy, financial sector reform, and privatization, with the remainder scattered across a fairly wide field. The structural conditions in the Fund's much discussed programs with three Asian crisis economies were more numerous and detailed than is usually the case. Financialsector conditions dominated in all three of those Asian programs but detailed conditions in quite a few non-core structural policy areas were also evident -- especially in the case of Indonesia. While much of the external criticism of Fund structural conditionality has emphasized the wide scope of the Fund's involvement (e.g., what has the Fund got to do with the clove monopoly), our review of the evidence suggests that the number and specificity of conditions in core areas ("micro mana gement") is at least as important an issue. ${ }^{40}$

Those analyzing Fund structural policy conditionality -- including researchers both inside and outside the Fund -- are unanimous in concluding that there has been a pronounced upward trend in such conditionality over the past fifteen years, and this trend has probably become steeper in the 1990s. ${ }^{41}$ The evidence reported in this section (much of it previously unpublished) strongly corroborates this conclusion. Finally, there has also

\footnotetext{
${ }^{40}$ Saying that the Fund has "micro-managed" some structural reforms is not the same as saying that such reforms necessarily lack macroeconomic impact. For example, a condition to reduce significantly the extent of wage indexation could be very detailed but might still carry macro impact.
} 
been a shift over time in the instruments used by the Fund to monitor structural $\underline{\text { conditionality, with resort to structural benchmarks, conditions for program reviews, and }}$ prior actions having risen faster than formal performance criteria. Prior to the 1980 s, the Fund was hesitant to ask for prior actions, and performance reviews regarding structural policies were exceptional for standby arrangements. ${ }^{42}$ Structural benchmarks apparently were apparently not used prior to the establishment of the SAF in 1986. As demonstrated earlier, all this is no longer the case. For example, a comparison of the average number of structural conditions for standby arrangements in 1996-99 in Table 3 with the figures on structural performance criteria in Table 4 suggests that, taken together, $\underline{\text { structural }}$ benchmarks, prior conditions, and program reviews have recently been about five times $\underline{\text { as numerous as structural performance criteria. }}$

Writing well before Fund programs with the Asian crisis countries, Polak [1991] contrasted the principles put forth in the 1979 Guidelines on Conditionality with actual practice:

"... the guidelines do not attempt to change the structure of conditionality: their aim is limited to making that structure less intrusive by limiting the number of performance criteria, insisting on their macroeconomic character, circumscribing the cases for reviews, and keeping preconditions to a minimum. Yet these restraining provisions have not prevented the intensification of conditionality in every direction that the guidelines attempted to block." (p. 61).

Nine years later, it's hard to disagree with that assessment.

\section{B. The Effectiveness of Fund Structural Policy Conditionality}

If we take it as given that the Fund has become more "grandmotherly"/intrusive with regard to its structural policy conditionality, the next leading question is how effective

${ }^{41}$ See, for example, Tanzi [1987], Polak [1991], Killick [1995], James [1998], Krueger [1998], Mussa and Savastano [1999], Gupta et al. [2000]. 
has such conditionality been? ${ }^{43}$ Here, we address just two aspects of that question: the degree of compliance with Fund conditions, and the quality of the Fund policy advice implicitly reflected in such structural policy conditionality. Again, much of the available evidence is often not in the form best suited to the focus of this paper (that is, it refers to compliance with, or the effectiveness of all Fund policy conditions -- not just structural policies; or when it deals just with structural policies, it covers only low-income or transition economies). Nevertheless, some conclusions can be put forward. In addition, some of the recent research on compliance with structural conditions in Fund programs with the transition economies is particularly interesting.

(i) Compliance with Fund policy conditions -- Clearly, Fund policy conditionality cannot have its intended effects if countries do not implement these policies. Two measures of compliance are typically found in the literature; the share of IMF loans actually disbursed; and the degree of compliance with particular Fund policies (e.g, credit ceilings, budget deficits, various structural benchmarks). ${ }^{44}$

Table 10, adopted from Mussa and Savastano [1999], shows the share of Fund lending actually disbursed for 615 Fund programs over the 1973-97 period. While the authors caution that a low disbursement share could mean the program was so successful -- or conditions improved so rapidly -- that the country needed to use only a fraction of the committed IMF financing, they conclude that low disbursement cases mainly were ones where the program went off track (because policies deviated significantly from those agreed and subsequent negotiations failed to reach agreement on a modified program).

\footnotetext{
${ }^{42}$ See Polak [1991] and IMF [1987].

${ }^{43}$ The description of Fund conditionality as being "grandmotherly" is from Keynes; see James [1998].

${ }^{44}$ Another potential measure of compliance would be the share of programs that saw an early conversion of the program to a precautionary arrangement.
} 
Here, it is appropriate to highlight three of the Mussa-Savastano findings. First, if we take say, disbursement of 75 percent or more of the total loan as implying close adherence to IMF policy conditionality, then less than half (45.5 percent) of all Fund arrangements over the entire 1973-97 period would have met that test; see column (6) in Table 10. Second, again using the 75 percent or greater benchmark, the completion rate for standby arrangements (48.5 percent) was notably higher than that for EFF programs (25.4 percent) with higher average structural policy content; the completion rate for SAF/ESAF arrangements, which also have a relatively high structural policy content and deal exclusively with low-income countries, was much higher than for EFFs and only slightly below that for SBAs. And third, there is a suggestion that the completion rate for Fund programs is declining over time. ${ }^{45}$

A very similar exercise on completion rates was undertaken by Killick [1995] for 305 Fund programs over the $1979-93$ period, with results quite close to those obtained by Mussa and Savastano [1999]. Killick [1995] defines a "completed program" as one that disbursed 80 percent or more of the total Fund loan. He finds that on this measure: 47 percent of Fund programs were completed, that the completion rate was higher for SBAs than for EFFs, that the completion rate was declining over time, and that completion rates do not differ (in the expected way) on account of cross-country differences in either percapita income or type of export. ${ }^{46}$

Most earlier studies that looked at compliance with particular Fund policies were restricted to macro conditionality. In brief, Beveridge and Kelly [1980] and Edwards

\footnotetext{
${ }^{45}$ I use the term, "suggestion," because Mussa and Savastano [1999] note that the results on completion rates for the 1993-97 period are biased downward due to the inclusion of arrangements with post-1997 expiration dates.
} 
[1989] found that compliance with monetary and/or fiscal performance criteria was observed in approximately 48-62 percent of Fund programs. Polak [1991] updated these results for SBA, EFF, and SAF programs in the 1980s and found that compliance rates for the 1980s were below those for the 1970s. Killick [1995] cites one unpublished 1991 IMF study that looked at compliance with structural policies in SAF and ESAF programs: slightly over half of all structural benchmarks were observed on schedule (or two thirds within a few months thereafter); and compliance was relatively high for agricultural producer-pricing and marketing and for financial reforms, and relatively low for fiscal provisions (and especially for public enterprise reforms).

Two more recent studies of compliance with Fund structural conditionality have been conducted for the transition economies by Christiansen and Richter [1999] and MercerBlackman and Unigovskaya [2000]. ${ }^{47}$ Four of their findings are of interest. First, the ontime compliance rate for structural benchmarks as a group averaged 42 percent, with an additional 16 percent of conditions met with delay; the remaining 42 percent of conditions were either not met or no information was available. Second, the compliance rate for performance criteria (both macro and structural taken together) was higher than that for structural benchmarks. Third, the correlation between the number of structural benchmarks in a program and the completion rate for those structural policies was negative, although neither large nor statistically significant. And fourth, while there was sizeable variation in the compliance rate across structural reform categories, the standard

\footnotetext{
${ }^{46}$ Killick [1995] did find some evidence that completion rates were lower for highly-indebted countries and for those that received relatively low access to Fund resources.

${ }^{47}$ A caveat should be noted with respect to studies of the transition economies. Because of the centrality of structural policies to their reform efforts in the 1990s, their experience with structural policy conditionality may be "special" and not necessarily transferable to economies where structural policies occupy a less central role.
} 
deviation of compliance across countries was more than twice as great as that for compliance by reform category. ${ }^{48}$

To sum up, existing studies suggest that obtaining compliance with Fund conditionality has been a serious problem, including the Fund's structural policy conditionality. The compliance problem has been getting more serious over time. Compliance has been lower for EFF programs than for standby arrangements (but not apparently for SAF/ESAF programs). Compliance has also been lower for structural benchmarks than for performance criteria. Correlations between the compliance rate and the number of $\underline{\text { structural conditions, along with measures of the variability of compliance across }}$ program areas and countries suggest that greater selectivity both in the countries approved for structurally-oriented programs and in the structural measures included in $\underline{\text { such programs could have a high pay-off in terms of compliance rates. }}{ }^{49}$ Further studies on a broader sample of countries would be useful in sharpening these conclusions, including the important issue of whether or not the product of the number of structural conditions and the compliance rate is approximately a constant.

(ii) Effectiveness of structural policy conditionality -- Even if countries consistently complied with Fund structural policy conditions, this would not necessarily constitute an endorsement for such conditionality unless it can be shown that these are "good" structural policy requirements that lead to "better" economic performance. Evidence relevant for answering that latter query can be gleaned from at least five sources: (a)

\footnotetext{
${ }^{48}$ The on-time compliance rate was highest (57 percent) for public wage and employment conditions and lowest (29 percent) for price and marketing conditions. Ukraine had the lowest overall compliance rate (14 percent of structural conditions met on time), while Lithuania had the highest (82 percent).

${ }^{49}$ It is relevant to note that the 1979 "Conditionality Guidelines" suggest that the Managing Director of the IMF should only recommend that the Fund's Executive Board approve a program when it is his judgement that the program..... will be carried out;" see Guideline Number 7 in Table 2.
} 
econometric studies that estimate the effects of IMF programs (as a whole) by comparing program and non-program countries/periods; (b) studies that relate either structural policy action within a Fund program or structural policy action more generally (whether in Fund programs or otherwise) to economic growth; (c) studies that relate measures of corporate governance to the extent of exchange rate depreciation or stock market decline during the Asian crisis; (d) a comparison of Fund structural policy recommendations with the "consensus" of the economics profession on what are "good" structural policies; and (e) a review of the Fund's structural policy recommendations in the Asian crisis countries.

(a) Studies on the effects of IMF programs as a whole -- By now, there is an extensive empirical literature on the effects of IMF programs. ${ }^{50}$ If one defines "program effects" as the observed outcome (for growth, inflation, the balance of payments, etc) relative to the "counterfactual" (that is, the outcome in the absence of an IMF program), then it is clear that most of the early literature had serious methodological flaws. "B1 "Before-after" comparisons are not reliable because they attribute all the change in outcomes to a Fund program when exogenous shocks and other influences may really be causing that change. Comparison of program targets and outcomes will not be useful when program targets are set too ambitiously or not ambitiously enough. Simulations of economic models can tell us something about the effect of Fund-type policies but not about the effects of actual Fund programs. And comparisons of outcomes for program and non-program countries will not do the job if the two groups differ systematically in ways that matter for economic performance. Over time, most of these methodological problems have been addressed. Nowadays, studies typically seek to identify program effects after controlling

\footnotetext{
${ }^{50}$ For a recent survey of this literature, see Haque and Khan [1998].

${ }^{51}$ See Goldstein and Montiel [1986].
} 
both for non-program effects and for observed (pre-crisis) differences between program and non-program countries.

Still, even the best studies have only indirect implications for the effectiveness of Fund structural policy conditionality since they do not disaggregate the contents of a Fund program into its macro and structural policy components. In any case, what such studies usually find is that Fund programs have a favorable impact on the current account and overall balance of payments, that the effect on inflation is statistically insignificant, and that the effect on economic growth is initially (with the first year) negative but probably turns positive at longer time horizons, ${ }^{52}$ too little econometric work has been done on income distribution to say much. ${ }^{53}$

One possible explanation for why such studies do not generate large positive growth effects for Fund programs is that compliance with the policies that matter for medium to long-run growth is far from complete (as demonstrated above); also, some countries that are in trouble implement on their own policies that are not so different than those included in Fund programs. It has also been argued that even non-program countries have been influenced by the "silent revolution" in economic thinking on the importance of sound macroeconomic and structural policies and that the Fund has contributed importantly to this revolution (that is, non-program countries are not a good "control group" because they too are affected by the policy treatment). ${ }^{54}$ A second explanation is that the lags associated with the effects of structural policies on economic growth are long and hence, may show up only after the country has left a Fund program. Yet a third

\footnotetext{
${ }^{52}$ See Mussa and Savastano [1999], Fischer [2000b], and Conway [1994].

${ }^{53}$ See, however, the recent study by Garuda [2000] who finds that Fund programs improve income distribution and poverty reduction for countries with relatively modest pre-crisis external disequilibria but worsen them for countries with severe pre-crisis external imbalances.
} 
explanation is that the results are right: despite all the rhetoric on "growth-oriented adjustment," Fund programs are still mainly about getting out of financial crises and don't much matter for growth in the medium to long-run.

(b) Links between broad measures of structural policy reform and growth -- This is a more recent literature, much of it connected with understanding the economic performance of the transition economies. ${ }^{55}$

One strand looks at whether greater compliance with Fund structural policy conditionality is associated with better growth performance. Here, the recent study by Mercer-Blackman and Unigovskaya [2000] is worth noting. They find that, after controlling for other factors, those transition economies that demonstrated higher compliance with IMF structural performance criteria had better records of sustained economic growth (defined as three consecutive years of positive real GDP growth); in contrast, they could find no significant association between compliance with Fund structural benchmarks and sustained growth. They also report that transition economies that did better on complying with Fund structural performance criteria also showed greater progress on implementing structural reform more generally. ${ }^{56}$ One interpretation of their first finding is that the (relatively few) structural policies included as performance criteria are more important for growth than the larger number regarded as structural

\footnotetext{
${ }^{54}$ See, for example, Krueger [1998].

55 There is of course a much broader and older literature on effects of alternative structural-policy strategies (e.g., Balassa's [1983] work on outward-looking vs. inward-looking policy strategies) and on the determinants of growth in developing countries more generally (e.g., Barro [1996]). In addition, there are many studies that take a non-quantitative approach to evaluating Fund s tructural policies; see, for example, Schadler et al. [1995] who (looking at Fund programs during the 1988-92 period) concluded that "...there was a broad measure of success in accomplishing structural reform...." (p. 29).

${ }^{56}$ Progress on structural reform is measured using a structural reform index, derived from De Melo et al. [1996] and EBRD Transition reports. This index is meant to capture liberalization of prices and foreign exchange markets, small and large-scale privatization, governance and restructuring reforms, legal reforms, interest rate liberalization, and banking reforms; see Havrylyshyn et al. [1999].
} 
benchmarks. The authors concede that some of their results are also consistent with other views; for example, countries with better growth performance may find it easier to implement Fund structural conditions, and the unobserved "commitment to reform" may explain both Fund program implementation and progress on structural policy action more generally.

The other strand of this literature tests for an association between structural reform -whether achieved within the context of a Fund program or not -- and economic growth. A good example is the recent study by Havrylyshyn et al [1999], which examines the growth experience of 25 transition economies over the 1990-97 period. After attempting to hold other determinants of growth constant (including initial economic conditions, inflation, size of government, degree of openness, etc), they find that the greater was progress on an index of overall structural reform, the higher was economic growth. ${ }^{57}$ They also tested whether individual components of structural reform aided growth but found that only price liberalization had significant explanatory power when the overall reform index was also included -- a finding which they interpret as suggesting that it is the "combination" of structural policies that is more critical for growth than any single type of policy.

A similar growth exercise for 84 low and middle-income countries during the 1981-95 period is summarized in IMF [1997]. In these pooled, cross-section regressions, the authors find that after controlling for other determinants of per capita GDP growth, improved macroeconomic policies and improved structural policies both have significant

\footnotetext{
${ }^{57}$ Fischer et al [1996] reached a similar conclusion in an earlier paper on the growth experience of the transition economies. Because there are very few transition economies that have not had a program with the IMF, a comparisons of program and non-program countries is not a viable research strategy.
} 
effects on growth in the expected direction. They also conclude that behavior of growth in ESAF countries does not differ fundamentally from that in other developing countries.

(c) Corporate governance and the Asian financial crisis -- As suggested earlier, there has been much discussion of the role that governance and corruption issues played in the Asian financial crisis. A new study by Johnson et al [2000] provides some interesting empirical results and insights. The authors look at the behavior of nominal exchange rates and stock markets from the end of 1996 through January 1999 for 25 emerging economies. Their aim was to see if cross-country differences in measures of corporate governance (e.g., judicial efficiency, corruption, rule of law, protection for minority shareholders, creditor rights, etc.) could do a better job at explaining the extent of exchange rate depreciation and stock market decline than could standard macroeconomic measures (e.g., fiscal and monetary policy, current account imbalances, international reserves, foreign debt, etc.). In brief, they find that the corporate governance horse does better than the macroeconomic horse, particularly for stock market movements. They argue that "institutions' that protect investor rights are not important as long as growth lasts (because managers do not want to steal). But when growth prospects decline and there is even a small loss of investor confidence, countries with only weakly enforceable minority shareholder rights become particularly vulnerable. This is because outside investors reassess the likely amount of expropriation by managers and adjust the amount of capital they are willing to provide (resulting in a fall of asset values and a collapse of the exchange rate). On some of Johnson et al's measures of corporate governance -particularly rights of minority shareholders -- several Asian crisis countries (particularly 
Indonesia and Thailand) ranked low and hence, were more vulnerable to the effects of a downturn.

(d) Fund structural policy conditionality and the "consensus" -- In 1983 at a conference on IMF conditionality, Richard Cooper [1983] offered the following view:

“... we could choose any five people present and make a team to work up an economic adjustment program for a particular country other than our own... the program we came up with not differ greatly from a typical IMF program.” (p. 571).

I am more skeptical that we could make the same statement today, at least about Fund programs for the Asian crisis countries. Nevertheless, I would still maintain that the general thrust of the Fund's structural policy recommendations falls squarely in what my IIE colleague, John Williamson [1990] has labeled "the Washington policy consensus." Whether it's interest rate deregulation, trade liberalization, tax reform, the currency regime, foreign direct investment, price liberalization, or banking reform, Fund structural policy advice is typically not far from the consensus. Writing 15 years after Cooper, Ann Krueger [1998] offers a similar assessment:

"Many of the lending changes supported by the Bank and the Fund (in, for example, exchange rates, size of fiscal deficits, trade liberalization, agricultural and energy price reforms, privatization, and tax reform) are ones that would be endorsed in broad outline, if not in detail, by almost all economists."

But saying that the Fund's structural policy advice has generally reflected the profession's consensus view does not mean that this advice has not at times gone seriously astray. Three examples illustrate the point. First, along with several of its larger G-7 shareholders (particularly the U.S. and the U.K.), the Fund often pushed hard on emerging economies to undertake capital account liberalization without due regard to the 
adequacy of the host country's regulatory and supervisory framework. ${ }^{58}$ In Korea, for instance, the Fund apparently urged liberalization of both short-term and long-term flows. ${ }^{59}$ But when the Koreans said they would only go for the former, the Fund apparently regarded this as better than nothing and accepted it. ${ }^{60}$ A second example concerns Fund advice on privatization in transition economies. There, the Fund [2000] acknowledges that privatization runs the danger of producing perverse results in the absence of hard budget constraints, competition, and effective standards of corporate governance. As with capitalaccount liberalization, a more selective approach to privatization with greater attention to sequencing would, with the benefit of hindsight, have been better. Yet a third example was the initial Fund recommendation in Indonesia to go with a limited deposit guarantee for banks rather than a blanket guarantee. ${ }^{61}$ In drawing the lessons of the Asian crisis, the Fund (Lindgren et al. [1999]) now concludes that in a systemic crisis a blanket guarantee is needed to restore confidence in the financial system. ${ }^{62}$

(e) Fund structural policy conditionality in the Asian crisis countries --I will confine my remarks on the Fund's structural policy recommendations to four points.

First, I find the underlying rationale for dealing immediately with insolvent and weak banking and finance companies compelling. Without such action, it probably would have

\footnotetext{
${ }^{58}$ One of the few observers who stated publicly his concerns (before the crisis) about the magnitude of short-term capital inflows going into Asian emerging economies was Park [1996].

${ }^{60}$ In appraising Fund structural policy recommendations made in the late 1980s, Schadler et al.[1995, p. 31] similarly conclude: “.... Coordinated programs for structural reforms would have been desirable but were generally not politically or administratively feasible. It is appropriate, therefore, that programs supported the second-best strategy of seizing opportunities for reform on as broad a front as possible. This process cannot give a large role to sequencing considerations, but these are not unambiguous and could unduly slow the process."

${ }^{61}$ A comprehensive guarantee was introduced in Indonesia two months later.

${ }^{62}$ As suggested below, I do not share this view on the use of blanket guarantees but many others do.
} 
been impossible to restore monetary and currency stability (since large-scale liquidity support to insolvent institutions would have worked at cross-purposes), and the fiscal tab for bank recapitalization would have been even higher than it has turned out to be (since managers of insolvent institutions would have engaged in more "gambling for resurrection"). Moreover, I don't think confidence could have been restored without some concrete evidence that financialsector supervision (including transparency and disclosure) was going to be "started" on a different path for the future than it had been on in the past. Similarly, to show that cronyism and corruption would henceforth be less prevalent, it was important (at least in Indonesia) to take a few visible privileges/sweetheart deals away from those close to President Suharto. Once the crisis deepened and non-performing loans of banks and corporate insolvencies became larger and more widespread, it also became evident that banks and corporates -- particularly in Thailand and Indonesia -- would not simply be able to grow out of it without restructuring. Because of strong links between banks and corporates (especially in Korea and Indonesia), as well as the need to cushion somewhat the most vulnerable groups from the effects of the crisis, there was a good case for including some corporate reforms (e.g., reduction of debt-equity ratios by the chaebol) and some social safety net provisions in those programs.

Second, notwithstanding the above argument, there were elements of structural conditionality in the three Fund programs with Indonesia, Korea, and Thailand that seem superfluous. I don't find persuasive the argument that trade liberalization measures in the Indonesian and Korean programs were necessary to prevent a slide toward 
protectionism. ${ }^{63} \mathrm{~A}$ better rationale would be that trade liberalization was needed to increase competition and to help discipline inefficient domestic producers. But that still doesn't argue for why trade liberalization needed to be done immediately rather than after the crisis. Likewise, I don't see why the Indonesian program had to be so sweeping with respect to dismantling of state monopolies and cartels, elimination of restrictive marketing agreements, abolition of showcase projects, and the like -- disagreeable as those practices were. For "confidence" reasons, a few "candies" may have had to be taken away from cronies at the outset but the rest of the box (and admittedly, it was a very big box) could have waited for later. In the Korean program, the tax reform and privatization conditions look like they could have waited until after the crisis. And in Thailand (which had the narrowest of the three programs), it's hard to see why privatization of state enterprises, removal of the real estate tax on foreign purchases of condominiums, and a new land act needed to be part of the Fund's conditions.

Moving from the width to the depth of conditionality, the level of detail reflected in the structural benchmarks for these three programs likewise seems excessive. For example, in Indonesia, was it necessary to have five commitments for reform of oil and gas policy, and 18 commitments for follow-up actions to the findings of the audit of Bank Indonesia? In Korea, was it essential to have 11 commitments for restructuring, for investment guidelines, and for corporate governance of insurance companies? And in Thailand, did 6 target dates have to be set up to guide the privatization of Bangkok Metropolitan and Siam City banks? More generally, did supervisory and prudential measures for financial institutions in the three crisis countries have to be specified so precisely; wouldn't say, a broader commitment to implement the Basle Core Principles of Effective Banking

${ }^{63}$ See Hamann and Shulze-Ghattas [1999]. 
Supervision by date $\mathrm{x}$, along with a few benchmark checks of good progress, be as effective (and less intrusive) and, in addition, carry the seal of approval of the world's key banking supervisors? Couldn't the Fund provide its very detailed views on ways of improving corporate governance as technical assistance -- not as conditions in the Fund program? Yes, this would require more faith that the crisis country would want on its own to "do the right thing." But if it doesn't really want to implement the reforms, then very detailed monitoring via a very large set of structural benchmarks may not push the ball much farther ahead. Besides, unlike performance criteria, failure to meet many of the structural benchmarks does not carry the automatic threat of interruption of Fund financing.

Third, I don't agree with either the Fund or many of its critics that the Indonesian experience leads to the lesson that bank restructuring during a systemic banking crisis can only be accomplished successfully if blanket guarantees are issued by the government. ${ }^{64}$ The closing of banks in Indonesia led to runs because the authorities were only willing to close a subset of a much wider group of insolvent banks, because high- level political support (from President Suharto and some others) for the initial bank closures was absent, and because the Fund agreed to a bad compromise. When there are widespread bank insolvencies, the key to restoring confidence is to convince the public that all the bad banks have been closed or resolved, that the remainder are solid, and that small retail depositors (not everybody) will be covered. ${ }^{65}$ As a former colleague of mine put it, "people don't run banks that are closed; they run banks that are open that they think will soon be closed." Also, when there is no deposit insurance in place or the insurance

\footnotetext{
${ }^{64}$ See Lindgren et al. [1999].
} 
system is not viewed as credible, the necessity is for the bank supervisory authority to replace the old management of insolvent banks with a new one (so as to prevent "double or nothing" behavior and even larger credit losses), and to eventually dock the shareholders (so as to penalize the owners and to limit moral hazard); such insolvent banks can then be resolved in a variety of alternative ways (even while they honor withdrawals and take deposits). What's not necessary -- and can prompt runs -- is to board up the teller cages of some banks (while other questionable banks remain open). The real lesson of the Indonesian experience is that a sensible, incentive-compatible, deposit insurance system (along the lines of FDICIA in the United States) should be permanent part of the financial infrastructure in all countries; without it, governments wind-up providing ex post deposit insurance but they do it at higher current cost and with moral hazard effects that increase the likelihood of future banking crises.

A recent World Bank report supports the view that blanket guarantees are not the answer to resolving emerging-market financial crises. After conducting empirical tests based on data from 700 corporations in nine crisis countries (including three Asian crisis countries), Claessens et al. [2001] conclude that:

"The analysis on data of corporate sector performance suggests that unlimited government guarantees on bank liabilities have no impact on both the recovery and sustainability. Given that they are fiscally very costly, this suggests governments should avoid guarantees." (p.19).

In much the same spirit, I disagree with those who say that bank capital requirements should have been phased-in even more slowly in the Asian crisis countries so as to prevent a credit crunch. A cutback in lending exposure is an equilibrium response of a bank to a negative shock that reduces its capital. The relevant question is not whether one

\footnotetext{
${ }^{65}$ Ways to limit moral hazard without negating the benefits of deposit insurance are discussed in Financial Stability Forum [2000].
} 
likes a credit crunch; it is whether one prefers some credit crunch to an expansion of lending -- much of which is likely to go to the same insolvent borrowers that were at the root of the banks' difficulties (leading to even large bank losses). To be sure, there was a fall-off in real credit supply in late 1997 and early 1998 in most of the crisis countries, and undoubtedly some "good" borrowers were also denied credit. But there was also a fall in real credit demand that apparently was sharper than the fall in supply (at least in Korea and Thailand) ${ }^{66}$ in addition, there is some evidence that the allocation of bank credit improved. ${ }^{67}$ In the end, I doubt whether we would have obtained a better combined score card on economic activity and on bank losses if capital requirements were less binding during 1998-2000.

Drawing on a sample of 34 countries ( 27 of them developing or transition economies) which have experienced significant fiscal costs from bank failures over the 1970-2000 period, Honohan and Klingebiel [2000] compare "regulatory forbearance" versus "strict" approaches to crisis resolution. They find that unlimited deposit guarantees, open-ended liquidity support, repeated recapitalizations, debtor bail-outs, and regulatory forbearance add significantly and sizably to costs. And one of their main conclusions bears repeating:

“... our findings clearly tilt the balance in favor of a 'strict' approach to crisis resolution, rather than an accommodating one. At the very least, they emphasize that regulatory authorities which choose an accommodating or gradualist approach to an emerging crisis need to be sure that they have some other way of controlling risk." (p. 19).

Fourth, compliance with the Fund's structural policy conditionality appears to have been much better than the average (for all Fund programs) in Korea and in Thailand but not so in Indonesia. Notable progress has been made on financialsector rebuilding and

\footnotetext{
${ }^{66}$ See Ghosh and Ghosh [1999] and Lane et al. [1999].

${ }^{67}$ See Borenzstein and Lee [1999].
} 
reform but much remains to be done. And it's still too early to know whether the excessively close relationship between large business and government that has been the source of so much inefficiency and favoritism has changed fundamentally for the better. It's not easy (especially for an outsider) to measure compliance with structural policy conditions because the Fund programs with the three crisis countries were revised often over the 1997-2000 period, and because some structural benchmarks have been dropped/added from one revis ion to the next. Still, suppose we define compliance as having met a condition within say, three months of the target date. Then my ballpark estimate would be that Korea has complied with about 90 percent of the structural conditions laid out in the Fund's program. ${ }^{68}$ The corresponding compliance figure for Thailand would be about 70 percent. Two areas where compliance was weak in Thailand were reform of state banks and privatization of public enterprises. The calculation for Indonesia is subject to the largest margin of error but probably falls in the $20-40$ percent range. In Indonesia, compliance with structural conditions has been seriously handicapped by prolonged political instability and by a weak approach by the government toward debtors; compliance has been lower in non-core policy areas than in core areas.

The problem with just looking at the share of structural conditions met is not only that some are more important than others, it is also that most structural policy conditions capture processes that do not necessarily have a tight link with outcomes. For example, if the structural benchmark says you must have two outside directors appointed to a

\footnotetext{
${ }^{68}$ During a visit to South Korea in May 2000, I met with many Korean officials who had been involved in the crisis negotiations with the Fund. My overall impression is that most of the structural conditions included in the Fund program had been on the domestic reform agenda for a long time and thus were not
} 
corporate board, that can be done but the outside appointees may not differ much from their predecessors. Or a loan can be "restructured" but in a way that doesn't much reduce the present discounted value of the borrower's debt burden. For this reason, it is useful to look at some other, less process-oriented benchmarks for the financial and corporate sectors.

As background, we should recall that the three crisis countries (as a group) experienced a sharp output recovery in 1999 and 2000; inflation is low in Thailand and moderate in Korea; low interest rates have helped to support the recovery; and current accounts are in surplus (although much reduced from the huge current-account surpluses of 1998); see table 11. In addition, the crisis countries (as a group) have much lower ratios of shortterm external debt to international reserves than immediately preceding the crisis; they have abandoned publicly-declared exchange rate targets; and both non-performing loans in the banking system and corporate insolvencies are retreating from their peaks. They are moving in the right direction -- albeit much too slowly --on banking supervision and corporate governance. And in Korea, debt-equity ratios for most of the largest chaebol have declined sharply.

Turning to the negative side of the ledger: the sharp growth slowdown in the United States, along with the downturn in global electronics, have brought export growth throughout emerging Asian to a standstill and are likely to preface slower overall economic growth in the region for 2001 (see Table 11); Japan's faltering recovery, its continuing financial fragility, and a weaker yen have added to external strains; equity prices have declined sharply in the region; volatile oil prices remain a source of great 
uncertainty; public debt burdens have risen sharply in the crisis countries (reflecting the enormous fiscal costs of financial-sector restructuring) and, in concert with fiscal deficits, now limit the scope for counter-cyclical fiscal policy (at least outside Korea); bank lending to the private sector has generally been weak; and there are widespread and growing concerns that the pace, and particularly the quality, of financial-sector restructuring have been less satisfactory than hoped for a year or two ago.

Table 12, taken from Claessens et al. [1999], World Bank [2000], and national sources, provides a summary of financial restructuring in the three crisis countries (as of 19992000). A few additional comments can serve to supplement the information in table 12.

Korea has used a combination of recapitalizations, nationalizations, removal of bad debt, and mergers to strengthen its banking system. ${ }^{69}$ Investment trusts and merchant banks have undergone significant consolidation. Rapid economic growth in 1999-2000 aided the restructuring effort and the large build-up of international reserves has provided some protection against liquidity shocks. Banking supervision and regulation have been strengthened but risk management skills and practices on the ground are in need of substantial upgrading. The non-bank financial sector is still regarded as fragile. Despite considerable progress from pre-crisis levels, Korean corporations remain highly leveraged, profitability is low, and surveys suggest that interest coverage is a problem for many of them. A growing concern is that pressure for fundamental corporate

\footnotetext{
${ }^{69}$ See Lee [2001], Claessens et al. [1999], and World Bank [2000] for further discussion of the Korean restructuring program.
} 
restructuring is easing, reflecting, inter alia, government support to corporate bonds, labor disputes, and the political calendar. ${ }^{70}$

Thailand has closed about two-thirds of its finance companies but has gone slower on bank restructuring, asking the banks to raise their own capital and making injections of public money subject to stricter prudential and management changes. ${ }^{71}$ Until recently, the authorities opted for a decentralized approach to asset management companies. Although banks have raised large amounts of capital and comply with regulatory provisioning requirements, most independent analysts regard Thai banks as undercapitalized in an economic sense. Loan classification procedures for restructured loans are lax, and the share of non-performing loans (while much reduced from peak levels) is still high. Bank lending has declined. Corporate debt restructuring seems to have slowed after a promising start, and much of it has taken the form of maturity rescheduling. The judicial system is weak and has had difficulty coping with large caseloads. A noteworthy positive development has been the sale of local banks to foreign banks, bringing the latter's share of total banking assets to above 15 percent.

Turning to Indonesia, the sheer scale of problems, political instabilities, and a set of institutional weaknesses have combined to limit the progress made on financial restructuring. ${ }^{72}$ As indicated in table 12 , even after huge public outlays that have brought the state's ownership share of banking assets to more than 70 percent and that now mean that about 40 percent of fiscal revenues have to be directed to debt-servicing costs, the

\footnotetext{
${ }^{70}$ Other analysts (e.g., Root [2000] and Spencer [2000]) have pointed to the low number of affiliate sales by the chaebol and the rescue of Hyundai Engineering and Construction as disappointments in the Korean reform effort.

${ }^{71}$ See Tsao [2001a] for more on Thailand's financial restructuring.

${ }^{72}$ See Tsao [2001b], Claessens et al. [1999], and World Bank [2000] for discussion and evaluation of Indonesia's financial restructuring efforts.
} 
share of non-performing loans remaining in the banking system is much higher than in the other Asian crisis countries. Regulatory forbearance still exerts a large influence on loan classification practices, and the quality of loan restructuring is regarded as low. New bank lending has not resumed on any significant scale. The restructuring of state-owned banks has been slow. The recent depreciation of the rupiah and increases in interest rates have subjected financial restructuring to stronger head-winds. Notwithstanding a larger volume of corporate restructuring deals in the second half of 2000, the pace of asset disposition by the government-backed Indonesian Bank Restructuring Agency (IBRA) has been extremely slow. As outlined by Tsao [2001b], politically-powerful debtors seeking to avoid dilution of ownership, unrealistic valuations, a weak judicial system, and the size of the bad loan portfolio relative to the thinness of the market -- have all contributed to this unhappy outcome. Progress on voluntary out-of-court debt settlements has been evident but these account for only a tiny share of problem loans under IBRA's control. Stronger protection for creditors is needed, along with a greater emphasis on asset sales, new equity, and debt/equity conversions. Also high on the agenda should be further consolidation and recapitalization of banks and wide-ranging reforms of corporate governance. As indicated in table 12, corporate ownership remains highly concentrated among the top 15 families in all three Asian crisis countries.

To sum up, studies of the effects of Fund programs show that they have positive effects on the current account and overall balance of payments; effects on growth, inflation, and income distribution have proved to be much harder to pin down with any precision. Those transition economies that have done more on implementing Fund structural performance criteria appear to have done better on economic growth and structural policy 
reform more generally than those with weaker compliance records. Those emerging economies with better corporate governance structures in place prior to the outbreak of Asian crisis were, on average, hit less hard with currency and stock market declines during the crisis than those with a poorer track record on corporate governance. For the most part, Fund structural policy recommendations reflect the economics profession's $\underline{\text { consensus of what constitutes sensible structural policy reform, although some serious }}$ mistakes on sequencing of reforms have sometimes taken place. The "core" of the Fund's $\underline{\text { structural policy conditionality in the three Asian crisis countries -- which focused mainly }}$ on financialsector crisis-management and restructuring -- was appropriate, with the exception of the bad compromise made on bank closures in Indonesia. That said, the Fund's structural conditionality in the Asian crisis countries (and especially in Indonesia) appears "excessive"-- both in scope and in detail. Thus far, compliance with that conditionality has been high in Korea, above average in Thailand, and below average in Indonesia. Looking at a broader array of indicators, progress on restructuring in East Asia is visible but much more needs to be done to put banks and corporates on a sound footing. It is too early to tell whether the past close relationship between government and business has changed fundamentally for the better.

\section{HOW DID FUND STRUCTURAL POLICY CONDITIONALITY GET TO BE THIS WAY?}

If one concludes that Fund structural policy conditionality has become more intrusive than necessary, it is relevant to speculate on how it might have gotten that way. In my view, nine factors have contributed to that trend. ${ }^{73}$

\footnotetext{
${ }^{73}$ Several of these factors are discussed in Allen [1993].
} 
First, in the 1970s and early 1980s, Fund programs came under sharp criticism from many developing countries as being too demand-oriented and too short run, and as not paying enough attention to economic growth, to supply-side reforms, and to income distribution. The disappointing growth performance of developing countries in the early 1980s added to those concerns. Since it was developing countries that increasingly constituted the "demand" for Fund resources, neither the Fund nor creditor governments could easily dismiss that criticism. New lending windows with higher structural policy content and with lending terms more favorable to low-income countries were created, and monitoring techniques for gauging compliance with structural policy conditions evolved.

Second, the expansion of the IMF's surveillance responsibilities - agreed in the mid1970s under the second amendment of the Fund's charter and given expression in the revised Article IV - permitted Fund Article IV country missions to take a wider field of view in evaluating economic developments and prospects. Structural problems thus came under greater scrutiny. This greater familiarity with structural problems may in turn have led to a greater readiness to include structural policy conditions in programs - at least in those cases when structural weaknesses were perceived, rightly or wrongly, to have been linked to crisis vulnerability.

Third, the huge transformation task faced by the transition economies -- especially in the first half of the 1990s -- made structural policies and the building of a market infrastructure the name of the game in that region. And the IMF (along with the EBRD) was at the center of the technical assistance and policy lending to those transition economies. Again, structural benchmarks came to be relied upon as a way of monitoring 
structural policy conditionality across a wide front. When structural problems arose in later crises (Asia), the same monitoring techniques were applied.

Fourth, all the while, the Fund was more and more interpreting its mandate as broader than just promoting macroeconomic and financial stability and helping countries to manage financial crises. From the mid-1980s on, economic growth and later, high-quality growth, were given increased prominence. And after the Mexican peso crisis of 1994-95, crisis prevention -- with particular attention to strengthening financial systems at the national level and developing international standards and codes of good practice -- too moved up on the agenda.

Fifth, crises that involve severe balance-sheet problems of banks and private corporations lead to more structural policy intensive Fund programs than do those that stem from traditional monetary and fiscal policy excesses -- and the Asian crises of 199798 had those balance-sheet problems in spades. The IMF's Executive Board also seems to have sent staff the message (in 1997) that lending into serious governance and corruption problems (without any measures to address them) would not receive Board support. In the Indonesian program, a decision was made to try and impress the markets with the comprehensiveness of the reform effort.

Sixth, the long-standing and growing problem of obtaining good compliance with Fund programs led over time to greater reliance on prior actions and to more wide-ranging and detailed structural policy conditions -- presumably in an effort to penalize poor earlier track records, to thwart evasion, and to detect slippage at an earlier stage. ${ }^{74}$ If this broader and more detailed conditionality didn't produce higher compliance and the amount of 
structural reform hoped for, maybe the Fund concluded that it was still inducing more structural reform than would obtain with lesser Fund structural policy conditionality. The Fund's Guidelines for Conditionality -- which might have reined-in excessive structural policy conditionality --came to be viewed by the Fund's Executive Board as broad principles of intention -- not as something to be monitored carefully and enforced.

Seventh, in the meantime, a wide array of legislative groups, NGOs, and even other international financial organizations, came to the see an IMF letter of intent as the preferred instrument of "leverage" for their own agendas in emerging economies. Yes, the ILO might be the logical place to push core labor standards but it doesn't have the teeth of an IMF program. Simultaneously, various G-7 governments -- and particularly the Fund's largest shareholder -- were finding it increasingly difficult to get congressional support for "clean" IMF funding bills. Reflecting this congressional pressure from both major parties, the U.S. Executive Director at the Fund has been obliged to support with voice and vote a long list of structural policies (ranging from protection of the environment, to promoting economic deregulation and privatizing industry), and the U.S. Treasury is required to report annually to the Congress on its compliance with relevant sections of the Foreign Operations, Export Financing, and Related Programs Appropriation Act of 1999. A reading of that report (U.S. Treasury [2000b]) confirms that the United States frequently pushed for policies in Fund programs that were far from the Fund's core competence. Likewise, in countries where there was prolonged use of Fund resources, IMF letters of intent sometimes became an instrument of leverage which

\footnotetext{
${ }^{74}$ Failure to implement earlier Fund recommendations can over time push up structural conditionality even when some of those recommendations come in the form of technical assistance rather than as conditions in Fund programs.
} 
the Finance Ministry could use to push structural reforms on other departments in the government that were opposed. In short, everybody has gotten in on the act.

Eighth, unlike other IFIs, the Fund and the World Bank have sufficient "ground troops" to do on-site visits to all countries. In addition, at least in official circles, the Fund has developed a reputation as able to act quickly and efficiently. Whe n new structural challenges have arisen, there has therefore been a tendency to say, "give it to the Fund; they go there anyway; have them just add a few specialists on problem x to the mission." And the management of the Fund has apparently not said "no" very often to those demands.

Finally, there have been occasions -- the Korean and Indonesian programs are important cases in point -- when strong pressure from particular G-7 governments (during program negotiations) resulted in the inclusion of specific structural policies in a Fund program -- and this despite the provision in the Fund's charter (IMF [1988, p. 42], Article XII, Section IV) for each member country of the Fund to "... refrain from all attempts to influence any of the (Fund) staff in the discharge of [their] functions."

\section{APPROACHES TO STREAMLINING FUND STRUCTURAL POLICY CONDITIONALITY}

The Fund's new Managing Director, Horst Kohler, has already indicated that he thinks that the Fund "... has been overstretched in the past and needs to refocus (Kohler [2000a, p. 3]); he has also flagged his intention to end "mission creep" -- in large part by streamlining structural policy conditionality (Financial Times [2000b]). In seeking to carry out that objective, there are at least eight approaches (not all of them mutually exclusive) worth mentioning. 
(i) structural pre-conditions -- This radical approach, favored by the majority of the Meltzer Commission (see Meltzer Report [2000]), would jettison ex-post Fund conditionality in favor of a small number of pre-conditions, namely, freedom of entry and operation for foreign financial institutions, regular and timely publication of the maturity structure of outstanding sovereign and guaranteed debt and off-balance sheet liabilities, adequate capitalization of commercial banks, and a proper fiscal requirement. ${ }^{75}$ Developing countries that met these pre-conditions would be eligible immediately for short-term liquidity assistance; those developing countries that didn't meet them would not be eligible.

Objections to this approach have been registered on three counts. ${ }^{76}$

While meeting these pre-conditions would reduce the risk of getting into a crisis, they would hardly be sufficient for crisis prevention. Although many currency and debt crises begin in the banking sector, quite a few others do not, and freedom of entry plus a capital requirement are not good substitutes for the broader range of measures outlined in the Basle Core Principles of Effective Banking Supervision. ${ }^{77}$ The fiscal policy pre-condition is not defined in the report and making it operational would be subject to the same kind of negotiation and intrusiveness as with present Fund conditionality.

More fundamentally, even if satisfied, these pre-conditions would not get a country out of a balance-of-payments crisis once it got into one. Without measures to reduce absorption and to switch expenditure from foreign to domestic goods, the crisis country's

\footnotetext{
75 At present, the only Fund lending window that uses pre-qualification is the Contingency Credit Line (CCL). But since its inception in 1999, no country has yet come forward to use it.

${ }^{76}$ See Bergsten et al. [2000], U.S. Treasury [2000a], Goldstein [2001], Eichengreen [2000], and Williamson [2000].

${ }^{77}$ Garber [2000] has argued that a subordinated debt requirement for banks a la the Meltzer Report could easily be manipulated and evaded.
} 
ability to repay won't improve. And giving large Fund loans to a country with a runaway inflation and/or a huge budget deficit would increase moral hazard -- not reduce it.

Last but not least, it is highly questionable whether the international community would be willing to exclude completely from IMF financing countries that didn't meet these pre-conditions, particularly when a new government promised policies different from its predecessor. ${ }^{78}$ For this reason, the CFR Report [1999] rejected the "all or nothing" approach and opted instead to penalize (reward) countries that have followed poor (good) policies by charging them higher (lower) interest rates when they needed to borrow from the Fund.

(ii) collateralized Fund lending -- Another radical approach to reducing or eliminating Fund structural policy conditionality would have the Fund follow the Bagehot [1873] guideline and lend on good collateral. ${ }^{79}$ Good collateral is meant to serve several purposes. It provides a test of whether the borrower is just illiquid rather than insolvent (a solvent borrower has good collateral to pledge, an insolvent one does not). It safeguards the solvency of the lender. And it reduces (borrower) moral hazard by discouraging the borrower from holding risky assets that would not be accepted as good collateral.

Opposition to the collateral proposal emanates from several arguments. If eligible collateral is defined narrowly and strictly (say, holdings of U.S. government securities), then it won't provide much additional advantage in crisis management (since countries so endowed wouldn't need to come to the Fund -- they could borrow from private markets). Pledging collateral to the Fund might also run afoul of "negative pledge" clauses in

\footnotetext{
${ }^{78}$ See Polak [1991]. U.S. Treasury [2000a] argues that these pre-conditions would have precluded the IMF from responding to financial emergencies in the vast majority of its member countries, including all the Asian crisis countries.

${ }^{79}$ See Meltzer [1999] and Feldstein [1999].
} 
existing loan agreements and even if it didn't, its favorable impact would be limited since it would raise borrowing costs on the non-collateralized debt. Some would contend too that liquidating the collateral (say, export receipts) in the event of repayment problems (stemming either from bad luck or poor policy performance) would subject the Fund to even harsher criticism from developing-country borrowers than it receives when it interrupts disbursement under a Fund program. Would the United States, for example, have been able politically to cash-in the collateral (oil receipts) pledged by Mexico during the 1994-95 peso crisis if things had not worked out so well for Mexico in 1995?

(iii) define conditionality in terms of outcomes not structural policies or benchmarks -The idea here would be for the Fund to leave the process by which countries respond to crises up to them and instead condition Fund assistance on positive changes in certain outcomes. For example, instead of making changes in the judicial system or the establishment of a new framework for corporate debt restructuring conditions of the program for Indonesia, the Fund could just say that half of the non-performing corporate debt has to be rescheduled by date $\mathrm{x}$. If the country meets the target, it gets the money; otherwise, it doesn't.

The rub here is that performance criteria normally are confined to variables that are under the control of the borrower. The difficulty with defining structural conditionality only in terms of outcomes is that exogenous developments could affect the borrower's ability to meet the target. As such, there would be many demands for "waivers." In addition, outcomes are often not easy to define for some structural policies (e.g., what is "good" banking supervision, or what constitutes a "restructured" loan). And one of the main purposes of the Fund is to rule certain crisis- management processes (e.g.. increased 
resort to trade restrictions) as out of bounds. Still, it's possible that a mixed approach could be employed where some conditions would be defined in terms of outcomes, while others would be defined in terms of intermediate variables and/or processes.

(iv) Put restrictions or penalties on foreign-currency borrowing -- If much of structural policy conditionality comes from balance-sheet problems of banks and corporates and the latter, in turn, often derive from the build-up of large currency mismatches, why not attack the problem at its source by seeking to discourage foreign-currency borrowing? ${ }^{80}$ Presumably, a key reason why Brazil has had a much milder crisis than the Asian countries is that currency mismatching in Brazil was better controlled; hence, when the real crashed, there were many fewer banking and corporate insolvencies. While (enlightened) government borrowers ought to be able to internalize these externalities, not so for private borrowers who may expect either a government bail-out (if things go badly) or who may be driven to take up the cheaper foreign-currency loan because competitors are doing it. While timely publication of aggregate data on currency and maturity mismatching may improve market discipline, some have proposed going much farther. Krueger [2000], for example, has suggested that foreign-currency obligations incurred by domestic residents of emerging economies be made unenforceable in domestic courts. Others have argued that the currency mis-matching problem is a powerful argument in favor of dollarization.

One counter-argument is that such measures are too drastic for the problem at hand. If currency mis-matching is the problem, why not have the government develop better hedging mechanisms (e.g., futures exchanges), as Mexico has been doing since it moved to a floating rate. Others might say that giving up (via dollarization) the potential 
advantage of access to easy monetary policy during a severe recession just to minimize the risk of one particular type of crisis is allowing the tail to wag the dog. Enforcement of currency-matching restrictions could also be a problem. In today's world of structured derivatives, what looks like a domestic-currency loan could well have embedded options that amount to an unhedged bet on the exchange rate.

(v) greater resort to international standards -- Instead of custom-tailoring structural conditions to a particular crisis situation or particular financial institutions, the Fund and its member countries could rely more on generic international standards. For example, if there was a serious problem with data disclosure, or with banking supervision, or with corporate governance, the crisis country could agree to meet international standards in these areas by date $\mathrm{x}$. A potential appeal of the standards is that they represent the consensus on good practice in that area by a group of international experts -- not the views of an individual mission chief or even of the Fund. ${ }^{81}$ Since the Fund is already engaged (on a voluntary basis) in evaluating countries' compliance with standards and codes, this approach might also afford more flexibility in the time frame for meeting these conditions.

The disadvantage of the standards approach is that the standards themselves may not be specific enough to address the pressing problems at hand. If the elements of the standards are too vague, monitoring would likely lead to frequent disagreements.

(vi) leaner structural conditionality within present arrangements -- Under this approach, the Fund's Executive Board would issue a new guidance note calling for "leaner" structural conditionality; henceforth, each structural condition included in a program

${ }^{80}$ See Krueger [2000] and Dooley [1999].

${ }^{81}$ See Eichengreen [2000]. 
would have to be directly related to financial stability and would have to carry a macroeconomic impact; in addition, the note might increase the use of formal performance criteria relative to more discretionary structural benchmarks and program reviews. ${ }^{82}$ The aim of this new guidance note would not only be to induce mission chiefs to be less wide-ranging and detailed in their structural policy recommendations but also to dissuade both creditor and debtor governments from pushing for structural conditions that did not fall within the Fund's core competence (I'd like to help you Mr. Deputy Minister, but that just isn't our job). Associated with this leaner structural conditionality might also be an effort to increase the Fund's leverage for structural policy reform in non-program channels. For example, structural weaknesses could be given more attention in published Fund Article IV reports, leaving it more to the private markets to apply pressure for reform. And much of what now appears as detailed structural benchmarks (in a Fund program) on how to implement a given structural reform could be handled in Fund technical assistance.

Skeptics might argue that the existing guidance note on conditionality that has been around for twenty years or more is perfectly adequate. Why would a new one make much of a difference? To make a difference, manage ment and the Fund's Executive Board would have to be much more committed to enforcing the new note than they were in enforcing the previous one. But this would be unlikely to happen unless there was a clear "understanding" with the G-7 and with emerging economies that greater restraint would be exercised than heretofore in assigning the Fund new tasks. For example, just within the past few months, the G-7 has requested the IMF to step up its monitoring of money laundering. Questions would also arise on how many structural conditions and how much

\footnotetext{
${ }^{82}$ See the Postscript for excerpts from such a new (September 2000) guidance note on conditionality.
} 
detail would be appropriate for such a "leaner" structural conditionality (that is, would it be a big change from prevailing practice or only a small modification).

(vii) allowing the Fund to borrow in the private capital markets -- If some G-7 legislatures use the Fund's requests for funding (increases in quota, funding for new facilities and debt initiatives, etc) as points of "leverage" to impose a variety of (counterproductive and superfluous) conditions on Fund lending practices, it might be argued that the Fund should be given authority to borrow in the private capital markets (thereby increasing its independence). ${ }^{83}$ Those who oppose this proposal would contend that the Fund itself -- not G-7 legislatures -- is the main source of excessive structural conditionality; as such, easier funding would reduce "accountability" to the Fund's shareholders and might just as well increase the scope of Fund conditionality as reduce it. (viii) clearer division of responsibility with the World Bank and more outsourcing of structural conditionality in non-core areas -- The aim here is to retain the advantages of a "comprehensive" approach to crisis prevention/management, sustainable growth, and poverty reduction, while improving the effectiveness of (total) structural policy conditionality by paying greater attention to the different comparative advantages of the various IFIs. Even if the number of structural conditions in Fund programs remained unchanged, the Fund would design and monitor only those conditions which fit within its defined "core competence" (say, monetary, fiscal, exchange rate, and financial-sector policies); anything else, would be the responsibility of the World Bank or other IFIs. If one of the other IFIs was not moving fast enough in drafting a structural policy requirement, the Fund would not be permitted to take over. It would have to stay in its

\footnotetext{
${ }^{83}$ Another proposal for reducing political demands on the Fund is go to "independent" Executive Directors -- much in the manner of national central banks; see De Gregario et al. [1999].
} 
own yard. Under some proposals, the Fund would transfer primary responsibility for running the Poverty Reduction and Growth Facility (PRGF) to the World Bank, although the Fund would still have a sign-off on the adequacy of macroeconomic policies in such programs with low-income countries. Under other proposals (see Kohler and Wolfensohn [2000]), the Bank would get its own new lending window (the Poverty Reduction Support Credit) to support poverty reduction in low-income countries, and the Fund would continue to run and fund the PRGF. Renewed efforts would also be made to improve Fund/Bank cooperation.

Here too, there are many potential objections and questions. If the problem is too much and too detailed structural policy conditionality as a whole, why would rearranging responsibilities among the IFIs solve it? If the PRGF is about poverty reduction and if that is supposed to be the main focus of the World Bank, why does the Fund run that facility? If it's true, as suggested by the U.S. Treasury [2000b], that unless the Fund's Board has its own money at stake, Fund evaluation of macroeconomic policies in programs with low-income countries won't be done seriously (even with a formal signoff in programs run by the Bank), why should we expect other IFIs to be diligent in their evaluation of structural policies in Fund-led programs? Why do we need two lending facilities (the existing PRGF in the Fund, and the new PRSC in the Bank) to support poverty-reduction and macroeconomic stability in the low-income countries; wouldn't one make more sense? How will the Fund and Bank cooperate more closely with other international organizations (e.g., OECD, BIS, ILO, WTO, etc) under the "contracting-out model" and still meet the demanding time requirements of crisis resolution? 


\section{CONCLUDING REMARKS}

$\underline{\text { I agree with Stanley Fischer's [2000b, p. 2] assessment that “... the IMF.... promotes }}$ good macroeconomic and financial-sector policies among its members." But my reading of the record is that on structural policies the Fund has bitten off more -- in both scope and detail -- than either it or its member countries can chew. There are limits -- no matter how numerous and detailed the Fund's monitoring techniques -- to how far the Fund can push a country to undertake structural reforms that it itself is not strongly committed to. Consistent with this view, compliance with Fund conditionality has been a serious and growing problem. IMF mission chiefs have considerable knowledge and experience in macroeconomic and financial policies but not in structural policy areas beyond this core competence. Efforts to include in Fund conditionality everything but the kitchen sink under the a loosely defined agenda of pursuing "high quality" growth have taken the Fund too far from its comparative advantage and have elicited legitimate charges of "mission creep."

Among the alternative crisis ma nagement guidelines discussed in Section II, the one (Mandate II) that would have the Fund focus on macroeconomic and financial stability and assist a country not only to get out of its current crisis but also to minimize the chances of getting into another one makes the most sense to me. Conditions that lie outside the core areas of monetary, fiscal, exchange rate, and financial-sector policies should be significantly fewer in Fund programs than the average of the past five years and should require strong justification in any program, including having a macroeconomic impact (as called for in the original conditionality guidelines for stand-by programs). I also read the record as suggesting that the effectiveness of Fund structural 
conditionality would be increased if a small number of structural performance criteria were substituted for the vast array of structural benchmarks that have characterized many past Fund programs. This would require Fund staff to think harder about which structural conditions merited the highest priority in the reform effort, and about which structural policy changes needed to be done now (during the crisis) and which could wait until somewhat later; putting more weight on a few structural performance criteria would also send a clearer signal to the borrower that failure to meet those performance criteria would likely result in a halt in Fund disbursements.

Last but not least, streamlining and improving Fund structural policy conditionality is about Fund management saying "no" more often than in the past -- to requests for Fund assistance where the expectation is low that the country will actually implement Fund policy conditions, to G-7 governments when they propose new tasks for the Fund that go beyond the Fund's core competence, to NGOs who seek to use a country's letter-of-intent with the Fund to advance agendas (even if desirable) that lie outside the Fund's mandate and comparative advantage, and to developing-country finance ministries that want to use micro conditions in Fund programs to impose spending discipline on other government ministries that could not be obtained via their national legislatures.

Mr. Kohler's intention to end mission creep at the Fund and to streamline the Fund's structural policy conditionality is welcome. But it remains to be seen how he will pursue that objective and what the effects will be.

$$
* * * * * *
$$




\section{POSTSCRIPT}

The original version of this paper was presented in October 2000 at an NBER conference on "Economic and Financial Crises in Emerging Market Economies," held in Woodstock, Vermont; the paper has been revised in light of comments made at the Woodstock conference and of subsequent developments. In February 2001, the IMF published its own set of papers on conditionality in Fund-supported programs, including much new factual material on the Fund's involvement in structural policies (IMF [2001a, 2001b, 2001c, 2001d]). Of particular relevance, several of the new Fund papers contain a longer time-series on Fund structural conditions than was available when my paper was written. Specifically, the MONA data base figures for the 1993-99 period (used in my paper) were supplemented with data from country papers covering Fund programs approved over the 1987-92 period. In addition, IMF [20001c] presents some new results on implementation of Fund structural policies, obtained from a staff survey of recent programs in 24 countries. Also, a published summary of the recent IMF Executive Board discussion on conditionality in IMF programs (IMF [2001e]), along with a recent press briefing on this topic (Ahmed [2001]), shed light on how the Fund's views on the appropriate scope and detail of structural conditionality are evolving.

In my view, almost all the qualitative conclusions presented in my paper are reinforced by the new data contained in IMF [2001c], although there are, not surprisingly, some non-trivial differences between the Fund and me on the right interpretation of these data; in a few areas (e.g., the average number of structural conditions across different types of programs, that is, SBAs versus EFFs versus SAF/ESAF/PRGF), data for the longer period present a different picture than data for the 1996-99 or 1993-99 period. While one 
cannot hope to do justice in a brief summary to the wealth of factual material in IMF [2001c], I highlight below a number of key findings from the longer and/or more extensive data base; on a few points, I also provide my own interpretation of these findings.

(i) Structural conditionality in Fund-supported programs has increased substantially since the mid-1980s. In 1985-86, fewer than one-fifth of upper-credit-tranche SBAs and EFFs contained structural performance criteria; by the late 1980s, almost two-thirds of Fund programs were subject to structural conditiona lity of some kind, and by the mid1990s, the inclusion of structural conditionality was nearly universal. Likewise, the average number of total structural conditions (per year) in Fund programs has been on a steep upward trend since the mid-1980s -- rising from a mean of two per year in 1987, to seven in 1994 , to 14 in 1997-99.

(ii) While the rise in structural conditions over time applied to all types of monitoring instruments (prior actions, performance criteria, structural benchmarks, and program reviews), the rise in aggregate structural conditionality primarily reflects a proliferation of structural benchmarks. The next steepest increase was for prior actions and program reviews. The average number of structural performance criteria also increased since the late 1980s and early 1990s, but stayed in a relatively moderate range at or below two (per year).

(iii) While the share of programs with structural conditionality has always been higher for EFFs and for SAF/ESAF/PRGF programs than for SBAs, differences across types of programs in the average number of structural conditions (per year) have not been uniform over time and are not easy to generalize. On the whole, SAF/ESAF/PRGF programs 
appear to have been subject to a higher average number of structural conditions than either EFFs or SBAs; however, there have been years where the converse was true. For example, in both 1997 and 1995, the average was higher for SBAs than for SAF/ESAF/PRGF programs, and in 1996 and 1998, the average was higher for EFFs than for SAF/ESAF/PRGF programs. More often than not over the 1990s, SBAs have contained a higher average number of structural conditions per year than EFFs (although as noted in Section III of my paper, medians tell a different story than the means for the 1996-99 period). The distinction in structural conditionality between SBAs and EFFs has become increasingly blurred, reflecting the approval of SBAs with extensive structural content in the transition economies and in other countries.

(iv) According to the Fund's count, in 1997-98 the average number of total structural conditions in Fund programs with three Asian crisis countries (Indonesia, South Korea, and Thailand) was much higher than in programs with other non-transition, middleincome countries, somewhat higher than in (SAF/ESAF) programs with low-income countries, and somewhat lower than in programs with transition economies. Moreover, the (high average) figures for the Asian crisis countries were heavily influenced by the large number of structural conditions in the EFF program with Indonesia.

The Fund also notes that in addition to structural benchmarks, prior actions, performance criteria, and program reviews, many Fund programs contain extensive lists of structural measures in their letters of intent -- including detailed policy matrices with specific implementation schedules (of the kind displayed in Table 8 of this paper for Indonesia and used to estimate the number of structural policy commitments in Table 7). Since letters of intent are used to lay out the authorities' entire policy program and can 
include measures not formally covered by Fund conditionality, the Fund argues that using policy matrices to gauge Fund structural conditionality can lead to a gross overestimate of the scope and detail of such conditionality. At the same time, the Fund acknowledges that there appears to be a degree of substitutability between these matrices and structural benchmarks in practice, and that such policy matrices are sometimes viewed even within the Fund as part of Fund conditionality. Since the Fund's decision to support a country's program presumably depends on the totality of the country's policy commitments in relation to its policy problems, and since policy commitments made by the authorities on their own this period could, if not implemented, become part of Fund conditionality next period, I believe it is misleading to count in Fund conditionality only those policy commitments that are covered by formal Fund conditions. Nor do I see how any outsider (not privy to program negotiations) could tell which policy commitments were influenced by the Fund and which were not. In the end, counting all policy commitments with a specific implementation schedule (in the letter of intent) as part of Fund conditionality overstates true Fund conditionality, while excluding all commitments not covered by formal Fund monitoring instruments understates it. When all is said and done, I doubt that the overall appraisal on whether Fund structural conditionality has been appropriate will depend on these differences in the definition of the number of structural conditions (see discussion below).

(v) Until the mid-1980s, structural reforms in Fund programs were mainly confined to the exchange and trade system, with occasional forays into selected fiscal and financiat sector issues. In the late 1980s, Fund programs began to cover an increasing variety of structural measures. An index of concentration of Fund structural measures was 
constructed that takes on the value of one when all measures are concentrated in one sector and the value of zero whey they are uniformly distributed across 14 sectors. For all Fund programs, this index of concentration declined from 0.61 in 1987-90 to 0.45 in 1997-99, suggesting a trend inc rease in the breadth of structural conditionality. Still, close to two-thirds of Fund structural conditions relate to reforms in the fiscal and financial sectors, the exchange and trade system, and economic statistics. In all country groups, reforms in the fiscal and financial sector now play a dominant role.

(vi) The increase over time in the average number of structural conditions in Fund programs also reflects a trend toward greater detail in Fund monitoring. Whereas in 198793 close to two-thirds of the (cross-country) variation in the total number of structural conditions per program could be explained by variations in the breadth of programs' structural agenda, in 1994-99 variations in the scope of structural conditionality accounted for just 40 percent of the variation in structural conditions. The Fund concludes (IMF [2001c]) that greater detail in monitoring structural reforms may have played a more important role in contributing to the expansion of structural conditionality than coverage of a wider range of structural issues.

(vii) While the new Fund papers on conditionality (unfortunately) do not address issues of program design (i.e., whether the structural content of programs was appropriate), they do contain the results of a new staff survey of recent programs in 24 countries. The programs included were selected by area departments of the Fund and, in terms of regional coverage, were regarded as fairly representative of the total population of programs in recent years. 
The survey results indicated that less than 30 percent of the structural measures considered in Fund letters of intent were considered to be "critical" for the program's macroeconomic objectives, with another 40 percent seen as "important." The corresponding figures for structural measures subject to specific Fund conditions were 40 percent ("critical) and 33 percent ("important"). In my view, the finding that Fund staff itself regarded only 30-40 of all structural reforms included in Fund programs as "critical" for achieve ment of the program's macroeconomic objectives is consistent with an assessment that Fund structural conditionality has become excessive.

Another set of results from the staff survey related to the degree of implementation of structural reforms. Here, the main findings can be summarized as follows: (i) policy implementation in the structural area was not as good as in the macroeconomic area; (ii) some two-thirds of the structural measures in programs appeared to be fully implemented, many albeit with considerable delay; (iii) the average implementation rate was the lowest in the transition economies and in low-income countries with SAF/ESAF/PRGF programs; in contrast, the average implementation in the Asian crisis countries was nearly 90 percent; (iv) implementation rates were highest (80 percent) for prior actions, lower (66 percent) for performance criteria, and lowest (57 percent) for structural benchmarks; and (v) implementation rates (i.e, the share of measures implemented), while varying widely, are essentially uncorrelated with the number of structural conditions.

I suspect that the survey results may be biased upward with regard to implementation rates. I say that for several reasons. To begin with, since the countries selected for the survey were chosen by the area departments (rather than randomly or by the researchers 
doing the study) and since the answers provided by survey respondents may have been seen by them as reflecting on their own performance as mission chiefs and/or mission members, there is a danger of selection bias and of overly optimistic appraisals. In this regard, it is reported in IMF [2001c] that the average implementation rate was higher for the programs covered by the survey than for the larger sample of programs in the MONA data base. Second, the average implementation rate for all programs reported in the survey is not consistent with the implementation rates implied by the low share of Fund programs that exhibited full disbursement (see Table 10 in Section III). And third, the very high implementation rates reported by the survey for the Asian crisis countries (nearly 90 percent) are considerably above those that I have been able to obtain from analysis of Fund documents and from other sources of information; the low implementation rate for Indonesia alone would seemingly make it difficult to get a groupaverage implementation rate for the Asian crisis countries of nearly 90 percent.

Although clearly a useful first step, I would also question the robustness of the result (from bi-variate regressions) that the implementation rate for structural measures is unrelated to the number of structural conditions included in the program. Clearly, other factors (e.g., the degree of political instability in the program country) are likely to be important in determining implementation rates and these need to be held constant to isolate the independent effect of the extent of structural conditionality. I look forward to further empirical work on this issue.

(viii) Last but not least, taken as a group, recent Fund statements and papers on conditionality are much more accommodating (than their predecessors) to the views that 
past Fund structural conditionality may well have been excessive, and that efforts should be made to streamline such conditionality in the future.

One can see this shift of view in many places, including: in the broad thrust of the "Interim Guidance Note on Streamlining Structural Conditionality," issued by IMF Managing Director Kohler in September 2000 (Kohler [2000c]); in the new papers on Fund conditionality (IMF [2001]) reviewed above; in the published summing-up of the IMF's Executive Board's recent (March 21, 2001) discussion of conditionality (IMF [2001e]; and in recent press briefings given by senior IMF staff administering conditionality (e.g.Ahmed [2001]. A number of excerpts from these publications illustrates the new push for "parsimony" and "prioritization" in structural conditionality.

"If structural reforms meet the macro-relevance test but are neither critical nor in the Fund's core areas of responsibility, Fund conditionality would generally not apply." "Streamlining Structural Conditionality in Fund-Supported Programs: Interim Guidance Note"

Issued by IMF Managing Director, Horst Kohler, September 2000, Kohler [2000c].

"While experiences regarding the extent of structural conditionality and policy implementation have varied widely across countries, there are indications that in a significant number of cases, structural conditionality has moved beyond what seems consistent with the principal of parsimony, underscoring the need for streamlining .... It points to the need for greater prioritization based on the importance of specific structural reforms for a program's macroeconomic objectives."

"Structural Conditionality in Fund-Supported Programs, "IMF [2001c], p. 85.

"The scope of structural conditionality should be streamlined following two main approaches. One is by limiting Fund conditionality to what is essential (and not merely relevant) to program objectives. A second, which is applicable to PRGF countries, is to make use of a coordination framework to achieve a better division of labor with the World Bank, permitting each institution to confine conditionality to its core areas while ensuring that the concerns of both institutions are satisfied."

“Conditionality in Fund-Supported Programs -- Policy Issues," IMF [2001b], p. 44. 
“... Directors agreed that there was a need to streamline and focus the Fund's conditionality. The aim of the streamlining should be to leave the maximum possible scope for countries to make their own policy choices, while ensuring that the Fund's financing is provided only if these policies that are essential to the purposes of the Fund continue to be implemented."

"While these principles would need to be interpreted carefully on a case-by-case basis, they would shift the presumption of coverage from one of comprehensiveness to one of parsimony -- thus requiring a stronger burden of proof for the inclusion of specific structural measures as conditions in an arrangement, particularly where these measures were outside the Fund's core areas."

"Directors agreed that Letters of Intent (LOIs) should make a clearer distinction between the authorities' overall policy program and that part of the program that is subject to the Fund's conditionality."

"Since conditionality cannot compensate for the lack of program ownership, Directors agreed that the Fund should seek to limit its financing in such cases."

"IMF Executive Board Discusses Conditionality," Public Information Notice No. 01/28, March 21, 2001, IMF [2001e], pp. 1-4.

"If you look at the PRGF programs that have been approved by the Board, since the Interim Guidance Note was issued last September, on average, the number of structural conditions in them is significantly lower -- I believe it's about a third lower-- than the PRGF programs prior to that date."

Press Briefing on "IMF Conditionality," March 21, 2001, Ahmed [2001], p.9.

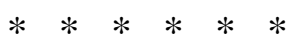




\section{SELECTED REFERENCES}

Ahluwalia, Pavan, 2000, "Discriminating Contagion: An Alternative Explanation of Contagious Currency Crises in Emerging Markets," IMF Working Paper No. 00/14, International Monetary Fund, Washington DC, February.

Ahmed, Masood, 2001, "Press Briefing on IMF Conditionality," http://www.imf.org/external/np/tr/2001/tr010321.htm (March 21).

Balassa, Bela, 1983, "The Adjustment Experience of Developing Countries after 1973", in John Williamson (ed.) IMF Conditionality, Washington DC, Institute for International Economics".

Barro, Robert, 1996, "Democracy and Growth", Journal of Economic Growth, 1, No. 1, (March), pp. 1-28.

Bergsten, C. Fred, 2000, "Towards a Tripartite World", The Economist, July $15^{\text {th }}$, pp. 2326.

Bergsten, C. Fred et al., 2000, "Reforming the International Financial Institutions," Minority Dissent to the Report of the International Institution Advisory Commission, Allan H. Meltzer, Chairman, Washington DC, March.

Beveridge, William A. and Margaret R. Kelly, 1980, "Fiscal Content of Financial Programs Supported by Stand-By Arrangements in the Upper Credit Tranches, 196978", Staff Paper No. 27, Washington DC, International Monetary Fund, June, pp. 205249.

Boorman, Jack, and others, 1999, "Managing Financial Crises: The Experience of East Asia," Paper presented at Carnegie-Rochester Public Policy Conference, Pittsburgh, November.

Bordo, Michael D. and Anna J. Schwartz, 1999, "Measuring Real Economic Effect of Bailouts: Historical Perspectives on How Countries in Financial Distress Have Fared With and Without Bailouts", Paper Prepared for the Carnegie Rochester Conference on Public Policy November 10-20, 1999.

Borensztein, Eduardo, 1994, "Structural Polices in Developing Countries", Paper on Policy Analysis and Assessment No. 19, Washington DC, International Monetary Fund, September.

Borensztein, Eduardo and Jong-What Lee, 2000, "Financial Crisis and Credit Crunch in Korea: Evidence from Firm-Level Data," IMF Working Paper WP/00/25, International Monetary Fund.

Botchwey, Kwesi, Jan Willem Gunning, Yusuke Onitsuka, and Koichi Hamada, 1998, 
External Evaluation of ESAF, International Monetary Fund, Washington DC.

Camdessus, Michel, 1990, "Remarks before the One-Asia Assembly", Manila, International Monetary Fund, February.

Camdessus, Michel, 1994, "International Cooperation for High-Quality Growth: The Role of the IMF at 50", Washington DC, International Monetary Fund, http://www.imf.org/external/np/sec/mds/1995/MDS9521.HTM (August 28, 2000).

Camdessus, Michel, 1997, “Good Governance, The IMF's Role”, Washington DC, International Monetary Fund, http://www.imf.org/external/pubs/ft/exrp/govern/govindex.htm (August 28, 2000).

Camdessus, Michel, 1999a, "Second Generation Reforms: Reflections and New Challenges", Washington DC, International Monetary Fund, http://www.imf.org/external/np/speeches/1999/110899.HTM (August 28, 2000).

Camdessus, Michel, 1999b, "Strengthening the Link Between Economic and Social Policies Within the Framework of a Globalized Economy", Washington DC, International Monetary Fund, http://www.imf.org/external/np/speeches/1999/102699.HTM (August 28, 2000).

Camdessus, Michel, 2000a, "Development and Poverty Reduction: A Multilateral Approach", Washington DC, International Monetary Fund, http://www.imf.org/external/np/speeches/2000/021300.HTM (August 28, 2000).

Camdussus, Michel, 2000b, "The IMF and Human Development: A Dialogue with Civil Society", Washington DC, International Monetary Fund.

Christiansen, Robert E. and Andrea Richter, 1999, "The Pattern of Structural Conditionality in Fund Programs with EU2 Countries", Washington DC, International Monetary Fund, August.

Chu, Ke-young, Sanjeev Gupta, Benedict Clements, Daniel Hewitt, Sergio Lugaresi, Jerald Schiff, Ludger Schuknecht, Gerd Schwartz, 1995, "Unproductive Public Expenditures: A Pragmatic Approach to Policy Analysis", Pamphlet Series No. 48, Washington DC, International Monetary Fund.

Claessens, Stijn, Simeon Djankov, and Daniela Klingebiel, 1999, "Financial Restructuring in East Asia: Halfway There?", Financial Sector Discussion Paper No. 3, Washington DC, The World Bank.

Claessens, Stijn, Daniela Klingebiel, and Luc Laeven, 2001, "Financial Restructuring in Systemic Crises: What Policies to Persue?" Washington DC, The World Bank, February, unpublished. 
Conway, P., 1994, "IMF Lending Programs: Participation and Impact", Journal of Development Economics, No 45, pp. 365-391.

Council on Foreign Relations Task Force, 1999, Safeguarding Prosperity in a Global Financial System: The Future International Financial Architecture, Carla Hills and Peter Peterson, Co-Chairs and Morris Goldstein, Project Director, Washington DC, Institute for International Economics.

Crow, John, Ricardo Arriazu, and Niels Thygensen, 1999, External Evaluation of IMF Surveillance, Washington DC, International Monetary Fund.

De Melo, M., C. Denizer, and A. Gelb, 1996, "Patterns of Transition from Plan to Market," World Bank Economic Review, September.

Dooley, Michael, 1999, "Debt Management in Developing Countries," mimeo, University of California at Santa Cruz, unpublished.

Edwards, Sebastian, 1989, "The International Monetary Fund and the Developing Countries: A Critical Evaluation", Carnegie-Rochester Conference Series on Public Policy, Volume 31, Autumn 1989, pp. 7-68.

Eichengreen, Barry, 1999, Toward a New International Financial Architecture: A Practical Post-Asia Agenda, Washington DC, Institute for International Economics".

Eichengreen, Barry, 2000, "Strengthening the International Architecture: Where Do We Stand?", Briefing Book from Symposium on Building the Financial System of the $21^{\text {st }}$ Century, Bretton Woods, pp. 157-196.

Eichengreen, Barry, and Ricardo Hausmann, "Exchange Rates and Financial Fragility", in New Challenges for Monetary Policy, Kansas City, Federal Reserve Bank of Kansas City.

Feldstein, Martin, 1998, "Refocusing the IMF", Foreign Affairs, March/April 1998, pp. 20-33.

Feldstein, Martin, 1999, “A Self-Help Guide for Emerging Markets”, Foreign Affairs, Vol. 78, No. 2, March/April, pp. 93-109.

Finch, C. David, 1983, “Adjustment Policies and Conditionality” in John Williamson (ed) IMF Conditionality, Washington DC, Institute for International Econmics.

Fischer, Stanley, Ratna Sahay, and Carlos A. Vegh, 1996, "Stabilization and Growth in Transition Economies: The Early Experience", The Journal of Economic Perspectives, Spring 1996, Volume 10, No. 2, pp. 45-66. 
Fisher, Stanley, 1997, "Applied Economics in Action: IMF Programs", AEA Papers and Proceedings, Vol. 87, No. 2, May, pp. 23-27.

Fischer, Stanley, 1999, “On the Need for an International Lender of Last Resort”, Washington DC, International Monetary Fund, January, http://www.imf.org/external/np/speeches/1999/010399.HTM (September 13, 2000).

Fischer, Stanley, 2000a, "Remarks by Stanley Fisher, Acting Managing Director", Remarks to the Bretton Woods Committee Meeting on April 4, 2000, International Monetary Fund, http://www.imf.org/external/np/speeches/2000/040400.htm (July 17, 2000).

Fischer, Stanley, 2000b, "Presentation to the International Financial Institution Advisory Commission (Meltzer Commission)", Washington DC, http://www.imf.org/external/np/speeches/2000/020200.htm (August 28, 2000)

Furman, Jason and Joseph E. Stiglitz, 1998, "Economic Crises: Evidence and Insights from East Asia", Brookings Papers on Economic Activity, No. 2, pp. 1-135.

Gaddy, Clifford and Barry Ickes, 1998, "Russia's Virtual Economy”, Foreign Affairs, September/October 1998, pp. 53-67.

Garber, Peter, 2000, "Notes on Market-Based Bank Regulation," in Joseph Bisignano et al (eds), Global Financial Crises: Lessons from Recent Events, Boston, Klewer Academic Publishers.

Garuda, Gopal, 2000, "The Distributional Effects of IMF Programs: A Cross-Country Analysis”, World Development, Vol. 28, No. 6, pp. 1031-1051.

Ghosh, Swati, and Atish Ghosh, 1999, "East Asia in the Aftermath: Was There a Crunch?” IMF Working Paper No. 99/38, International Monetary Fund, Washington DC.

Goldstein, Morris, 2001, “An Evaluation of Proposals to Reform the International Financial Architecture," Paper presented at NBER Conference on "Management of Currency Crises," Monterey, California, March 28-31.

Goldstein, Morris, 1998, The Asian Financial Crisis: Causes, Cures, and Systemic Implications, Policy Analyses in International Economics No. 55, Washington DC, Institute for International Economics.

Goldstein, Morris, 1997, The Case for an International Banking Standard, Policy Analyses in International Economics No 47, Washington DC, Institute for International Economics.. 
Goldstein, Morris and Peter Montiel, 1986, "Evaluating Fund Stabilization Programs with Multicountry Data: Some Methodological Pitfalls," IMF Staff Papers, Vol. 33, Washington DC, International Monetary Fund, June.

Group of Independent Experts, 1998, External Evaluation of the ESAF: Report by a Group of Independent Experts," Washington DC, International Monetary Fund, http://www.imf.org/external/pubs/ft/extev/index.htm (September 13, 2000).

Group of Seven Finance Ministers, 2000, "Strengthening the International Architecture: Report from G7 Finance Ministers to the Heads of State and Government", Fukuoka, July 8, http://www.mof.go.jp/english/if/if019.htm (July 14, 2000).

Group of Twenty-Four, 1987, The Role of the IMF in Adjustment with Growth, Washington DC, Intergovernmental Group of Twenty-Four on International Monetary Affairs.

Guitian, Manuel, 1995, “Conditionlity: Past, Present, Future," IMF Staff Papers, Vol. 42, No. 4, Washington DC, International Monetary Fund, December, pp. 792-835.

Guitian, Manuel, 1981, Fund Conditionality: Evolution of Principles and Practices, Pamphlet Series, No. 38, International Monetary Fund, Washington DC.

Gupta, Sanjeev, Benedict Clements, Calvin McDonald, and Christian Schiller, 1998, The IMF and the Poor, Pamphlet Series No. 52, Washington DC, International Monetary Fund.

Gupta, Sanjeev, Louis Dicks-Mireaux, Ritha Khemani, Calvin McDonald, and Marijn Verhoeven, 2000, Social Issues in IMF-Supported Programs, Occasional Paper 191, Washington DC, International Monetary Fund.

Haggard, Stephan, 2000, The Political Economy of the Asian Financial Crisis, Washington DC, Institute for International Economics, August.

Hale, David, 1998, "The IMF, Now More than Ever: The Case for Financial Peacekeeping", Foreign Affairs, Vol. 77, No. 6, November/December, pp. 7-13.

Hamann, Javier and Marianne Schulze-Ghattas, 1999, "Structural Reforms" in Lane et al. IMF-Supported Programs in Indonesia, Korean, and Thailand, Occasional Paper 178, Washington DC, International Monetary Fund.

Haque, Nadeem Ul and Mohsin Kahn, 1998, "Do IMF-Supported Programs Work?" Working Paper No. 169, Washington DC, International Monetary Fund.

Havrylyshyn, Oleh, and Donal McGettigan, 2000, "Privatization in Transition Economies", Post-Soviet Affairs, forthcoming. 
Havrylyshyn, Oleh, Thomas Wolf, Julian Berengaut, Marta Castello-Branco, Ron van Rooden, and Valerie Mercer-Blackman 1999, Growth Experience in Transition Countries, 1990-98, Occasional Paper 184, Washington DC, International Monetary Fund.

Heller, Peter S., A. Lans Bovenberg, Thanos Catsambas, Ke-Young Chu, and Parthasarathi Shome, 1988, The Implication of Fund-Supported Adjustment Programs for Poverty: Experience in Selected Countries, Occasional Paper 58, Washington DC, International Monetary Fund, May.

Honohan, Patrick, and Daniela Klingebiel, 2000, "Controlling Fiscal Costs of Banking Crises", Policy Research Working Paper No. 2441, Washington DC, The World Bank.

International Financial Institution Advisory Commission, 2000, "Report of the International Financial Institution Advisory Commission”, Allan H. Meltzer, Chairman, Washington DC, March (referred to above as the Meltzer Report).

International Monetary Fund, 1980, World Economic Outlook, Washington DC, IMF.

International Monetary Fund, 1987a, "Monitoring Techniques and Experience with Their Application to Structural Reform, Washington DC, IMF, unpublished.

International Monetary Fund, 1987b, Theoretical Aspects of the Design of FundSupported Adjustment Programs, Occasional Paper 55, Washington DC, IMF, September.

International Monetary Fund, 1993, Articles of Agreement, Washington DC, IMF, April.

International Monetary Fund, 1995, Financial Organization and Operation of the IMF, Pamphlet Series No. 45, Fourth Edition, Washington DC, IMF.

International Monetary Fund, 1997, The ESAF at Ten Years: Economics Adjustment and Reform in Low-Income Countries, Occasional Paper 156, Washington DC, IMF, December.

International Monetary Fund, 2000, World Economic Outlook, Washington DC, IMF, September.

International Monetary Fund, 2001a, "Conditionality in Fund-Supported Programs -Overview,"

http://www.imf.org/external/np/pdr/2001/eng/overview/index.htm (February 20).

International Monetary Fund, 2001b, "Conditionality in Fund-Supported Programs -Policy Issues," Washington DC, IMF, February.

International Monetary Fund, 2001c, "Structural Conditionality in Fund-Supported 
Programs," Washington DC, IMF, February.

International Monetary Fund, 2001d, “Trade Policy Conditionality in Fund-Supported Programs,"

http://www.imf.org/external/np/pdr/cond/2001/eng/trade/index.htm (February 16).

International Monetary Fund, 2001e, "IMF Executive Board Discusses Conditionality,"

Public Information Notice (PIN), No. 01/28,

http://www.imf.org/external/np/sec/pn/2001/pn0128.htm (March 21).

James, Harold, 1998, "From Grandmotherliness to Governance: The Evolution of IMF

Conditionality", Finance and Development, Volume 35, Number 4,

http://www.imf.org/external/pubs/ft/fandd/1998/12/james.htm (August 3, 2000).

Johnson, Simon, Peter Boone, Alasdair Breach, and Eric Friedman, 2000, "Corporate

Governance in the Asian Financial Crisis", Journal of Financial Economics, Volume

58, Number 1, http://www.jfe.rochester.edu/99362.pdf (September 13, 2000).

Killick, Tony, 1995, IMF Programmes in Developing Countries: Design and Impact,

London, Routledge.

Knight, Malcolm and Julio A. Santaella, 1997, "Economic Determinants of IMF

Financial Arrangements”, Journal of Development Economics, Vol. 54, pp. 405-436.

Köhler, Horst, 2000a, “Toward a More Focused IMF”, Address at the International Monetary Conference, May 30, 2000, Washington DC, International Monetary Fund.

Köhler, Horst, 2000b, "The IMF in a Changing World", Remarks to the National Press Club, August 7, 2000, Washington DC, International Monetary Fund.

Kohler, Horst, 2000c, "Streamlining Structural Conditionality in Fund-Supported Programs: Interim Guidance Note, " in IMF [2001b].

Krugman, Paul, 1998, “The Confidence Game,” New Republic, October.

Krueger, Anne, 1998, "Wither the World Bank and the IMF", Journal of Economic Literature, December, pp. 1983-2020.

Krueger, Anne, 2000, "Conflicting Demands on the International Monetary Fund," American Economic Review, May.

Lane, Timothy, Atish Ghosh, Javier Hamann, Steven Phillips, Marianne SchultzeGhattas, and Tsidi Tsikata, 1999, IMF-Supported Programs in Indonesia, Korea and Thailand, Occasional Paper No. 178, Washington DC, International Monetary Fund, 
Lee, Keon, 2001, "Korea: Financial and Corporate Reforms on Hold Until 2003," JP Morgan-Chase, Asian Economic Viewpoints, February 14.

Lindgren, Carl-Johan, Tomas J. T. Balino, Charles Enoch, Anne-Marie Gulde, Marc Quintyn, and Leslie Teo, 1999, Financial Sector Crisis and Restructuring: Lessons from Asia, Occasional Paper 188, Washington DC, International Monetary Fund.

McHale, John, 1998, "Capital Account Convertibility and Capital Controls in Emerging Market Countries: Some Themes from the First Meeting", Cambridge, Massachusetts, National Bureau of Economic Research, http://www.nber.org/crisis/capital.html (August 21, 2000).

McHale, John, 1999, "Currency and Financial Crises: The Case of Thailand. A Report on the First Country Meeting of the NBER Project on Exchange Rate Crises in Emerging market Economies", Cambridge, Massachusetts, National Bureau of Economic Research, http://www.nber.org/crisis/ThaiSum.html (August 21, 2000).

McHale, John, 2000a, "Brazil in the 1997-1999 Financial Turmoil. Fourth Country Meeting of the NBER Project on Exchange Rate Crises in Emerging market Economies", Cambridge, Massachusetts, National Bureau of Economic Research, http://www.nber.org/crisis/BrazilSum.html (August 21, 2000).

McHale, John, 2000b, "The Korean Currency Crisis. A Report on the Third Country Meeting of the NBER Project on Exchange Rate Crises in Emerging market Economies", Cambridge, Massachusetts, National Bureau of Economic Research, http://www.nber.org/crisis/KoreaSum.html (August 21, 2000).

Masson, Paul and Michael Mussa, 1995, "The Role of the Fund: Financing and its Interactions with Adjustment and Surveillance," Pamphlet Series, International Monetary Fund, Washington DC.

Meltzer, Allan, 1999, "What's Wrong with the IMF? What Would Be Better?" in William Hunter et al (eds)., The Asian Financial Crisis, Boston, Kluwer Academic Publishers.

Mercer-Blackman, Valerie and Anna Unigovskaya, 2000, "Compliance with IMF Program Indicators and Growth in Transition Economies", Working Paper No. 47, Washington DC, International Monetary Fund, http://www.imf.org/external/pubs/ft/wp/2000/wp0047.pdf, (September 13, 2000).

Mussa, Michael and Miguel Savastano, 1999, "The IMF Approach to Economic Stabilization" Working Paper No. 104, Washington DC, International Monetary Fund, http://www.imf.org/external/pubs/ft/wp/1999/wp99104.pdf (September 13, 2000). 
Nashashibi, Karim, Sanjeev Gupta, Claire Liuksila, Henri Lorie, and Walter Mahler, 1992, The Fiscal Dimensions of Adjustment in Low-Income Countries, Occasional Paper 95, Washington DC, International Monetary Fund, April.

Park, Yung Chul, 1996, "East Asian Liberalization, Bubbles, and the Challenge from China", Brookings Papers on Economic Activity, No. 2, pp. 357-371.

Polak, Jacques J., 1991, “The Changing Nature of IMF Conditionality”, Technical Paper No. 41, Paris, Organisation for Economic Co-Operation and Development, August, http://www.oecd.org//dev/PUBLICATION/tp/tp41.pdf (September 13,2000).

Radelet, Steven and Jeffery D. Sachs, 1998, "The East Asian Financial Crisis: Diagnosis, Remedies, Prospects", Brookings Papers on Economic Activity, No 1, 1998, pp. 1-74.

Rodrik, Dani, 1995, "Why is there Multi-lateral Lending?" CEPR Discussion Paper, No. 1207, London: Centre for Economic Policy Research.

Schadler, Susan, Adam Bennett, Maria Carkovic, Louis Dicks-Mireaux, Mauro Mecagni, James H. J. Morsink, and Miguel A. Savastano, 1995a, IMF Conditionality: Experience Under Stand-By and Extended Arrangements. Part I: Key Issues and Findings", Occasional Paper 128, Washington DC, International Monetary Fund, September.

Schadler, Susan, Adam Bennett, Maria Carkovic, Louis Dicks-Mireaux, Mauro Mecagni, James H. J. Morsink, and Miguel A. Savastano, 1995b, IMF Conditionality: Experience Under Stand-By and Extended Arrangements. Part II: Background Papers", Occasional Paper 129, Washington DC, International Monetary Fund, September.

Schadler, Susan, Franek Rozwadowski, Siddharth Tiwari, and David O. Robinson, 1993, Economic Adjustment in Low-Income Countries. Experience Under the Enhanced Structural Adjustment Facility, Occasional Paper 106, Washington DC, International Monetary Fund, September.

Schultz, George, 1995, "Economics in Action: Ideas, Institutions, Policies", The American Economic Review, Vol. 85, No. 2, May, pp. 1-8.

Spencer, Michael, 2001, "Economics: Assessing the Damage So Far,” Deutsche Bank Asia Window, April.

Stiglitz, Joseph E., 1999, "Reforming the Global Economic Architecture: Lessons from Recent Crises."

Summers, Lawrence, 1999, Statement at Meetings of IMF Interim Committee, September 1999 Annual Meetings of IMF and World Bank Group, Washington DC. 
Tanzi, Vito, 1987, "Fiscal Policy, Growth, and the Design of Stabilization Programs", A. Martirena-Mantel (ed.) External Debt, Savings, and the Growth in Latin America, Washington DC, International Monetary Fund.

Tsao, John, 2001a, "Thailand: Financial and Corporate Restructurings," JP MorganChase, Asian Economic Viewpoints, January 22.

Tsao, John, 2001b, “Indonesia's Monumental Restructuring Tasks," JP MorganChase, Asian Economic Viewpoints, February 16.

US Treasury, 2000a, Response to the Report of the International Financial Institution Advisory Commission, Washington DC, U.S. Department of the Treasury, June 8, http://www.ustreas.gov/press/releases/docs/response.pdf (September 13, 2000).

US Treasury, 2000b, Report on IMF Reforms, Washington DC, U.S. Department of the Treasury, March, http://www.treas.gov/press/releases/docs/imfrefor.pdf (September 13, 2000).

Volcker, Paul and Toyoo Gyohten, 1992, Changing Fortunes, New York, Times Books.

Williamson, John, 1990, "What Washington Means by Policy Reform", in J. Williamson (ed.) Latin American Adjustment: How Much Has Happened?", Washington DC, Institute for International Economics.

Williamson, John, 2000, “The Role of the IMF: A Guide to the Reports", International Economics Policy Briefs, No. 00-5, Washington DC, Institute for International Economics, May.

Wolfensohn, James, and Horst Köhler, 2000, "The IMF and the World Bank Group: An Enhanced Partnership for Sustainable Growth and Poverty Reduction", Washington DC, International Monetary Fund, http://www.imf.org/external/np/omd/2000/part.htm (September 7, 2000).

World Bank, 2000, East Asia: Recovery and Beyond, Washington DC, World Bank. 


\section{Table 1. Purposes of the IMF}

1. To promote international monetary cooperation through a permanent institution which provides the machinery for consultation and collaboration on international monetary problems.

2. To facilitate the expansion and balanced growth of international trade, and to contribute thereby to the promotion and maintenance of high levels of employment and real income and to the development of the productive resources of all members as primary objectives of economic policy.

3. To promote exchange stability, to maintain orderly exchange arrangements among members, and to avoid competitive exchange depreciation.

4. To assist in the establishment of a multilateral system of payments in respect of current transactions between members and in the elimination of foreign exchange restrictions which hamper the growth of world trade.

5. To give confidence to members by making the general resources of the Fund temporarily available to them under adequate safeguards, thus providing them with opportunity to correct maladjustments in their balance of payments without resorting to measures destructive of national or international prosperity.

6. In accordance with the above, to shorten the duration and lessen the degree of disequilibrium in the international balance of payments of members.

The Fund shall be guided in all its policies and decisions by the purposes set forth in this Article. 


\section{Table 2. Conditionality guidelines for Fund stand-by lending}

1. Members should be encouraged to adopt corrective measures, which could be supported by use of the Fund's general resources in accordance with the Fund's policies, at an early stage of their balance of payments difficulties. The article IV consultations are among the occasions on which the Fund would be able to discuss with members adjustment programs, including corrective measures, that would enable the Fund to approve a stand-by arrangement.

2. The normal period for a stand-by arrangement will be one year. If, however, a longer period is requested by a member and considered necessary by the Fund to enable the member to implement its adjustment program successfully, the stand-by arrangement may extend beyond the period of one year. This period in appropriate cases may extend up to but not beyond three years.

3. Stand-by arrangements are not international agreements and therefore language having a contractual connotation will be avoided in stand-by arrangements and letters of intent.

4. In helping members to devise adjustment programs, the Fund will pay due regard to domestic social and political objectives, the economic priorities, and the circumstances of members, including the causes of their balance of payments problems.

5. Appropriate consultation clauses will be incorporated in all stand-by arrangements. Such clauses will include provision for consultation from time to time during the whole period in which the member has outstanding purchases in the upper limit tranches. This provision will apply to whether the outstanding purchases were made under a stand-by arrangement or in other transactions in the upper credit tranches.

6. Phasing and performance clauses will be omitted in stand-by arrangements that do no go beyond the first credit tranche. They will be included in all other stand-by arrangements but these clauses will be applicable only to purchases beyond the first credit tranche.

7. The Managing Director will recommend that the Executive Board approve a member's request for the use of the Fund's general resources in the credit tranches when it is his judgement that the program is consistent with the Fund's provisions and policies and that it will be carried out. A member may be expected to adopt some corrective measures before a stand-by arrangement is approved by the Fund, but only if necessary to enable the member to adopt and carry out a program consistent with the Fund's provisions and policies. In these cases the Managing Director will keep Executive Directors informed in an appropriate manner of the progress of discussions with the member. 


\section{$\underline{\text { Table } 2 \text { (continued) }}$}

8. The Managing Director will ensure adequate coordination in the application of policies relating to the use of the Fund's general resources with a view to maintaining the nondiscriminatory treatment of members.

9. The number and content of performance criteria may vary because of the diversity of problems and institutional arrangements of members. Performance criteria will be limited to those that are necessary to evaluate implementation of the program with a view to ensuring that the achievement of its objectives. Performance criteria will normally be confined to (i) macroeconomic variables, and (ii) those necessary to implement specific provisions of the Articles or policies adopted under them. Performance criteria may relate to other variables only in exceptional cases when they are essential for the effectiveness of the member's program because of their macroeconomic impact.

10. In programs extending beyond one year, or in circumstances where a member is unable to establish in advance one or more performance criteria for all or part of the program period, provision will be made for a review in order to reach the necessary understandings with the member for the remaining period. In addition, in those exceptional cases in which an essential feature of the program cannot be formulated as a performance criterion at the beginning of a program year because of substantial uncertainties concerning major economic trends, provision will be made for a review by the Fund to evaluate the current macroeconomic policies of the member, and to reach new understandings if necessary. In these exceptional cases the Managing Director will inform Executive Directors in an appropriate manner of the subject matter of a review.

11. The staff will prepare an analysis and assessment of the performance under programs supported by use of the Fund's general resources in the credit tranches in connection with Article IV consultations and as appropriate in connection with further requests for use of the Fund's resources.

12. The staff will from time to time prepare, for review by the Executive Board, studies of programs supported by stand-by arrangements in order to evaluate and compare the appropriateness of the programs, the effectiveness of the policy instruments, and the observance of the programs, and the results achieved. Such reviews will enable the Executive Board to determine when it may be appropriate to have the next comprehensive review of conditionality. 


\section{Table 3. Number of programmed structural conditions per annum, 1996-99}

$\begin{array}{lcc} & \underline{\text { SBAs }} & \text { EFF } \\ \text { Median } & 9 & 18 \\ \text { Mean } & 15 & 18 \\ \text { Standard deviation } & 12 & 12\end{array}$


Table 4. Summary of Performance Criteria in Fund-Supported Programs: 1993-1999

TOTAL NUMBER OF ARRANGEMENTS

Number of programs approved by year

1993

1994

1995

1996

1997

1998

1999

Number of performance criteria

22

35

30

32

21

21

20

of which:

Quantitative performance criteria

419

328

234

203

Structural performance criteria

$\begin{array}{rrrrrrr}186 & 276 & 268 & 297 & 191 & 173 & 150 \\ 32 & 97 & 59 & 122 & 137 & 61 & 53\end{array}$

Per program:

Number of performance criteria

10

11

II

13

16

11

10

of which:

Quantitative performance criteria

Structural performance criteria

TRANSITIONECONOMIES

Number of programs approved by year

\begin{tabular}{|c|c|c|c|c|c|c|}
\hline 9 & 8 & 12 & 12 & 7 & 6 & 4 \\
\hline 82 & 79 & 100 & 156 & 73 & 90 & 37 \\
\hline 78 & 67 & 100 & 125 & 67 & 64 & 37 \\
\hline 4 & 12 & 0 & 31 & 6 & 26 & 0 \\
\hline 9 & 10 & 8 & 13 & 10 & 15 & 9 \\
\hline 9 & 8 & 8 & 10 & 10 & 11 & 9 \\
\hline 0.4 & 2 & 0 & 3 & 1 & 4 & 0 \\
\hline
\end{tabular}

Number of performance criteria of which:

Quantitative performance criteria

Structural performance criteria

8

8

9

9

4

9

7

8

3

3

\section{Per program:}

Number of performance criteria of which:

Quantitative performance criteria

Structural performance criteria

\section{ASIANECONOMIES}

Number of programs approved by year

Number of performance criteria

of which:

Quantitative performance criteria

Structural performance criteria

$\begin{array}{ccccccc}0 & 0 & 0 & 0 & 3 & 1 & 0 \\ 0 & 0 & 0 & 0 & 59 & 9 & 0 \\ 0 & 0 & 0 & 0 & 18 & 5 & 0 \\ 0 & 0 & 0 & 0 & 41 & 4 & 0\end{array}$

\section{Per program:}

Number of performance criteria

of which:

Quantitative performance criteria

$\begin{array}{rr}6 & 5 \\ 14 & 4\end{array}$

1/ Stand-by, Extended Facility, and SAF/ESAF/PRGF arrangements.

The number of performance criteria refers to all performance criteria over the duration of the program. Performance criteria are classified by year of program approval, irrespective of test dates they applied to. Quantitative performance criteria applying to the same variable are counted only once, even if observance was required for more than one test date. 
Table 5. Summary of Performance Criteria in ESAF/PRGF Arrangements: 1993-1999

\begin{tabular}{|c|c|c|c|c|c|c|c|}
\hline & 1993 & 1994 & 1995 & 1996 & 1997 & 1998 & 1999 \\
\hline \multicolumn{8}{|l|}{ TOTAL NUMBER OF ARRANGEMENTS } \\
\hline Number of programs approved by year & 7 & 13 & 7 & 14 & 7 & 11 & 9 \\
\hline $\begin{array}{l}\text { Number of performance criteria } \\
\text { of which: }\end{array}$ & \multicolumn{4}{|c|}{ of which: } & & 132 & 106 \\
\hline Quantitative performance criteria & 61 & 102 & 81 & 118 & 72 & 97 & 68 \\
\hline Structural performance criteria & 25 & 81 & 35 & 109 & 62 & 35 & 38 \\
\hline \multicolumn{8}{|l|}{ Per program: } \\
\hline $\begin{array}{l}\text { Number of performance criteria } \\
\text { of which: }\end{array}$ & 12 & 14 & 17 & 16 & 19 & 12 & 12 \\
\hline Quantitative performance criteria & 9 & 8 & 12 & 8 & 10 & 9 & 8 \\
\hline Structural performance criteria & 4 & 6 & 5 & 8 & 9 & 3 & 4 \\
\hline \multicolumn{8}{|l|}{ TRANSITION ECONOMIES } \\
\hline Number of programs approved by year & 1 & 1 & 0 & 3 & 1 & 3 & $\mathbf{0}$ \\
\hline $\begin{array}{l}\text { Number of performance criteria } \\
\text { of which: }\end{array}$ & \multicolumn{3}{|c|}{ of which: } & 60 & 17 & 42 & .. \\
\hline Quantitative performance criteria & 10 & 9 & .. & 33 & 13 & 31 & .. \\
\hline Structural performance criteria & 4 & 5 &.. & 27 & 4 & 11 & .. \\
\hline Per program: & & & & & & & \\
\hline $\begin{array}{l}\text { Number of performance criteria } \\
\text { of which: }\end{array}$ & 14 & 14 &.$\cdot$ & 20 & 17 & 14 & .. \\
\hline Quantitative performance criteria & 10 & 9 &.. & 11 & 13 & 10 & .. \\
\hline Structural performance criteria & 4.0 & 5 &.. & 9 & 4 & 4 & .. \\
\hline
\end{tabular}

1/ The number of performance criteria refers to all performance criteria over the duration of the program. Performance criteria are classified by year of program approval, irrespective of test dates they applied to. Quantitative performance criteria applying to the same variable are counted only once, even if observance was required for more than one test date. 
Table 6. Summary of Performance Criteria in SBAVFF Arrangements: 1993-1999

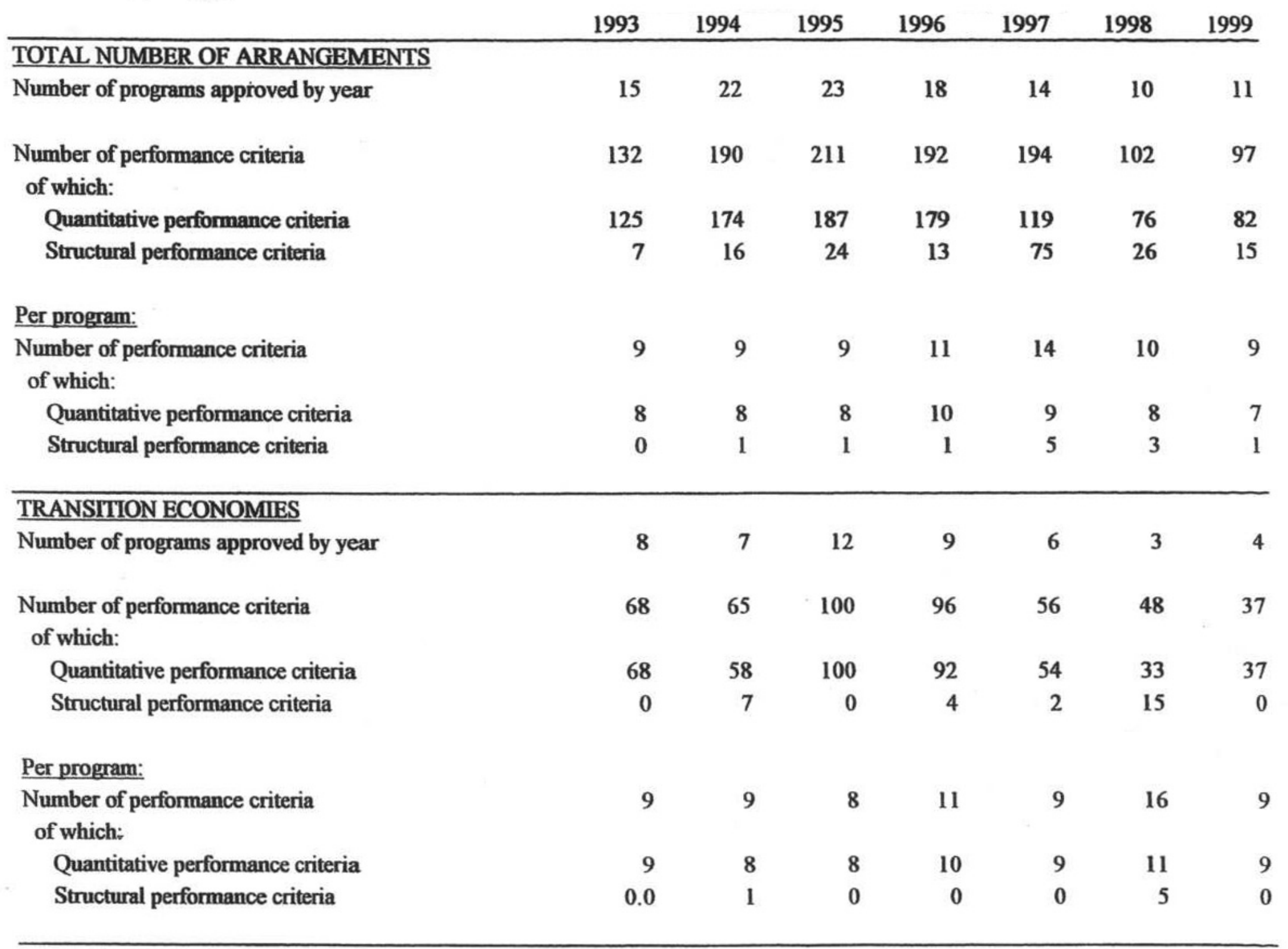

1/ The number of performance criteria refers to all performance criteria over the duration of the program. Performance criteria are classified by year of program approval, irrespective of test dates they applied to. Quantitative performance criteria applying to the same variable are counted only once, even if observance was required for more than one test date. 
Table 7. Number of Structural Policy Commitments in IMF Programs with Three Asian Crisis Countries, 1999-2000

\begin{tabular}{|c|c|c|c|c|c|c|c|c|c|c|c|c|c|}
\hline \multirow[t]{2}{*}{ Indonesia } & $10 / 97$ & $1 / 98$ & $4 / 98$ & $6 / 98$ & $7 / 98$ & $9 / 98$ & $10 / 98$ & $11 / 98$ & $3 / 99$ & $5 / 99$ & $7 / 99$ & $1 / 00$ & $7 / 00$ \\
\hline & 28 & 31 & 140 & 109 & 96 & 68 & 62 & 74 & 35 & 33 & 29 & 42 & 41 \\
\hline \multirow[t]{2}{*}{ South Korea } & $12 / 3 / 97$ & $12 / 5 / 97$ & $12 / 24 / 97$ & $2 / 98$ & $5 / 98$ & $7 / 98$ & $11 / 98$ & $3 / 99$ & $11 / 99$ & $7 / 00$ & & & \\
\hline & 29 & 33 & 50 & 53 & 51 & 39 & 53 & 83 & 94 & 68 & & & \\
\hline \multirow[t]{2}{*}{ Thailand } & $8 / 97$ & $11 / 97$ & $2 / 98$ & $5 / 98$ & $8 / 98$ & $12 / 98$ & $3 / 99$ & 9/99 & & & & & \\
\hline & 26 & 24 & 21 & 73 & 50 & 69 & 8 & 9 & & & & & \\
\hline
\end{tabular}


Table 8. Indonesia: Excerpts from Structural Policy Conditions

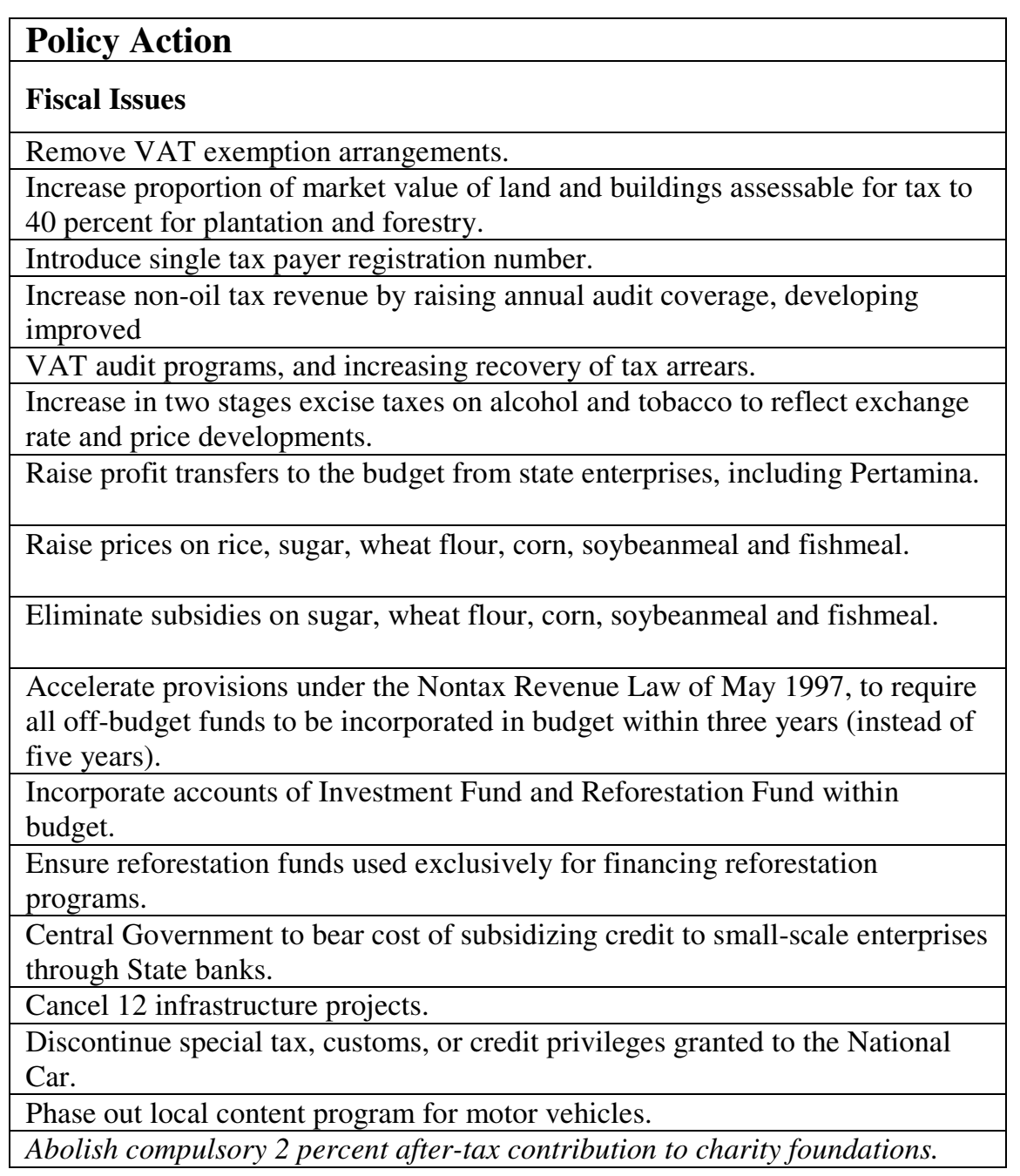

\begin{tabular}{|l|}
\hline Policy Action \\
\hline $\begin{array}{l}\text { Discontinue budgetary and extrabudgetary support and privileges to IPTN } \\
\text { (Nusantara Aircraft Industry) projects. }\end{array}$ \\
\hline
\end{tabular}

Conduct revenue review with Fund assistance.

\section{Monetary and banking issues}

Provide autonomy to BI in formulation of monetary and interest rate policy. Publish key monetary data on a weekly basis.

Submit to Parliament a draft law to institutionalize Bank Indonesia's autonomy. Submit draft amendment to banking law to Parliament.

Provide autonomy to state banks to adjust interest rates on credit and deposit liabilities, within any guidelines applying to all banks.

Impose limits on and phase out BI credits to public agencies and public sector enterprises.

Strengthen BI's bank supervision department and strengthen enforcement of regulations.

Upgrade the reporting and monitoring procedures for foreign exchange exposures of banks.

Appoint high level foreign advisors to BI to assist in the conduct of monetary policy.

Set minimum capital requirements for banks of Rp 250 billion by end-1998, after loan loss provisions.

Reduce the minimum capital requirements for existing banks.

Make loan loss provisions fully tax deductible, after tax verification.

Establish program for divestiture of BI's interests in private banks.

Require all banks to prepare audited financial statements. 


\section{Table 8 (continued)}

\section{Policy Action}

Require banks to publish regularly more data on their operations.

Lift restrictions on branching of foreign banks.

Submit to Parliament a draft law to eliminate restrictions on foreign investments in listed banks and amend bank secrecy with regard to nonperforming loans.

Eliminate all restrictions on bank lending except for prudential reasons or to

support cooperatives or small scale enterprises.

\section{Bank restructuring}

Close 16 nonviable banks.

Replace the closed banks' management with liquidation teams.

Compensate small depositors in the 16 banks.

Place weak regional development banks under intensive supervision by BI.

Provide liquidity support to banks, subject to increasingly restrictive

conditions.

Provide external guarantee to all depositors and creditors of all locally-

incorporated banks.

Establish Indonesia Bank Restructuring Agency (IBRA).

Determine uniform and transparent criteria for transferring weak banks to

IBRA.

Transfer 54 weak banks to IBRA

Transfer claims resulting from past liquidity support from BI to IBRA.

Transfer to IBRA control of seven banks accounting for over 75 percent of past BI liquidity support and seven banks that have borrowed more than 500 percent of their capital.

IBRA will continue to take control of or freeze additional banks that fail to meet liquidity or solvency criteria. Where necessary, any such action will be accompanied by measures to protect depositors or creditors in line with the

Government guarantee.

Issue presidential decree to provide appropriate legal powers to IBRA, including its asset management unit.

Take action to freeze, merge, recapitalize, or liquidate the six banks for which audits have already been completed.

Establish independent review committee to enhance transparency and

credibility of

IBRA operations.

\section{Policy Action}

Conduct portfolio, systems and financial reviews of all IBRA banks as well as major non-IBRA banks by internationally recognized audit firms.

Conduct portfolio, systems, and financial reviews of all other banks by internationally recognized audit firms.

Announce plan for restructuring state banks through mergers, transfers of assets and liabilities or recapitalization prior to privatization.

Ensure that state banks sign performance contracts, prepared by the Ministry of

Finance with World Bank assistance.

Merge two state-owned banks and conduct portfolio reviews of the two banks.

Draft legislation enabling state bank privatization.

Introduce private sector ownership of at least 20 percent in at least one state bank.

Prepare state-owned banks for privatization.

Develop rules for the Jakarta Clearing House that will transfer settlement risk

from BI to participants.

Introduce legislation to amend the banking law in order to remove the limit on

private ownership of banks.

Introduce deposit insurance scheme.

Establish Financial Sector Advisory Committee to advise on bank restructuring.

Declare insolvency of six private banks intervened in April and write down shareholder equity.

Issue government bonds to Bank Negara Indonesia at market-related terms to finance transfer of deposits of banks frozen in April.

Initiate first case of an IBRA bank under the new bankruptcy law.

\section{Foreign trade}

Reduce by 5 percentage points tariffs on items currently subject to tariffs of 15 to 25 percent.

Cut tariffs on all food items to a maximum of 5 percent.

Abolish local content regulations on dairy products. 


\section{Table 8 (continued)}

\section{Policy Action}

Reduce tariffs on nonfood agricultural products by 5 percentage points

Gradually reduce tariffs on non-food agricultural products to a maximum of

10 percentage points.

Reduce by 5 percentage points tariffs on chemical products.

Reduce tariffs on steel/metal products by 5 percentage points.

Reduce tariffs on chemical, steel/metal and fishery products to 5-10 percent.

Abolish import restrictions on all new and used ships.

Phase out remaining quantitative import restrictions and other nontariff barriers.

Abolish export taxes on leather, cork, ores and waste aluminum products. Reduce export taxes on logs, sawn timber, rattan and minerals to a maximum of

30 percent by April 15, 1998; 20 percent by end-December 1998, and 15 percent by end-December 1999 and 10 percent by end-December 2000 .

Phase in resource rent taxes on logs, sawn timber, and minerals.

Replace remaining export taxes and levies by resource rent taxes as appropriate.

Eliminate all other export restrictions.

Remove ban on palm oil exports and replace by export tax of 40 percent. The level of the export tax will be reviewed regularly for possible reduction, based on market prices and the exchange rate and reduced to 10 percent by endDecember 1999.

\section{Policy Action}

\section{Investment and Deregulation}

Remove the 49 percent limit on foreign investment in listed companies.

Issue a revised and shortened negative list of activities closed to foreign investors.

Remove restrictions on foreign investment in palm oil plantations.

Lift restrictions on foreign investment in retail trade.

Lift restrictions on foreign investment in wholesale trade.

Dissolve restrictive marketing arrangements for cement, paper and plywood.

Eliminate price controls on cement.

Allow cement producers to export with only a general exporters license.

Free traders to buy sell and transfer all commodities across district and provincial

boundaries, including cloves, cashew nuts and vanilla.

Eliminate BPPC (Clove Marketing Board).

Abolish quotas limiting the sale of livestock

Prohibit provincial governments from restricting trade within and between provinces.

Enforce prohibition of provincial and local export taxes.

Take effective action to allow free competition in:

(i) importation of wheat, wheat flour, soybeans and garlic;

(ii) sale or distribution of flour; and

(iii) importation and marketing of sugar.

Release farmers from requirements for forced planting of sugar cane. 
Table 9. Number of Structural Benchmarks (SBs) According to Structural Benchmark Groups for Countries in Transition

\begin{tabular}{|lrr|}
\hline Armenia & SBA & 35 \\
Azerbaijan & SBA & 26 \\
Belarus & SBA & 21 \\
Bulgaria & SBA & 19 \\
Macedonia & SBA & 19 \\
Romania & SBA & 19 \\
Estonia & SBA & 18 \\
Georgia & SBA & 17 \\
Hungary & SBA & 15 \\
Romania & SBA & 15 \\
Poland & SBA & 14 \\
Kazakhstan & SBA & 13 \\
Moldova & SBA & 13 \\
Ukraine & SBA & 12 \\
Uzbekistan & SBA & 12 \\
Croatia & SBA & 11 \\
Kazakhstan & SBA & 11 \\
Ukraine & SBA & 11 \\
Bulgaria & SBA & 8 \\
Kyrgyz Rep. & SBA & 6 \\
Russia & SBA & 23 \\
Moldova & SBA & 6 \\
Poland & SBA & 5 \\
Latvia & SBA & 3 \\
Bulgaria & SBA & 2 \\
Latvia & SBA & 11 \\
Average for SBA & & 1 \\
Kyrgyz Rep. & EFF & 13 \\
Albania & & 35 \\
Azerbaijan & EFF & 34 \\
Georgia & ESAF & 31 \\
Armenia & ESAF & 22 \\
Macedonia & ESAF & 18 \\
Average for ESAF & 17 \\
Azerbaijan & ESAF & 26 \\
Russia & ESAF & 41 \\
Kazakhstan & & 37 \\
Moldova & 23 \\
Lithuania & & 16 \\
Croatia & EFF & 11 \\
Average for EFF & & 23 \\
\end{tabular}


Table 10: Percentage of IMF Loan Actually Disbursed under Each Arrangement, distribution by quartiles
(1)
(2)
(3)
(4)
(5)
(6)
(7)

Fully Disbursed (4)+(5) Number of

\begin{tabular}{|c|c|c|c|c|c|c|c|}
\hline All Arrangements & $x<0.25$ & $0.25=<x<0.50$ & $0.50=<x<0.75$ & $0.75=<<1.0$ & $(x=1.0)$ & $0.75=<x$ & Arrangements \\
\hline $1973-77$ & 36.5 & 7.1 & 5.9 & 5.9 & 44.7 & 50.6 & 85 \\
\hline 1978-82 & 19.4 & 16.1 & 10.5 & 12.9 & 41.1 & 54.0 & 124 \\
\hline 1983-87 & 12.9 & 15.8 & 19.4 & 7.9 & 43.9 & 51.8 & 139 \\
\hline 1988-92 & 17.5 & 15.1 & 20.6 & 14.3 & 32.5 & 46.8 & 126 \\
\hline $1993-97$ & 27.0 & 19.1 & 26.2 & 11.3 & 16.3 & 27.6 & 141 \\
\hline Full period (1973-97) & 21.6 & 15.3 & 17.6 & 10.7 & 34.8 & 45.5 & 615 \\
\hline \multicolumn{8}{|l|}{ of which } \\
\hline Stand-By & 23.1 & 13.4 & 15.0 & 9.5 & 39.0 & 48.5 & 441 \\
\hline EFF & 33.3 & 22.2 & 19.0 & 15.9 & 9.5 & 25.4 & 63 \\
\hline SAF/ESAF & 9.0 & 18.9 & 27.0 & 12.6 & 32.4 & 45.0 & 111 \\
\hline
\end{tabular}

Source: IMF, Transactions of the Fund (1998) 
Table 11. Asian Crisis Countries: Real GDP, Consumer Prices, and Current Account Balance

$\begin{array}{clccc} & & \begin{array}{c}\text { Real GDP } \\ \text { (annual \% change) }\end{array} & \begin{array}{c}\text { Consumer Prices } \\ \text { (annual \% chang) }\end{array} & \begin{array}{c}\text { Current Account Balances } \\ \text { (as \% of GDP) }\end{array} \\ \text { Indonesia } & 1998 & -13.0 & 58.0 & 4.2 \\ & 1999 & 0.3 & 20.8 & 3.7 \\ & 2000^{*} & 4.8 & 3.8 & 2.0 \\ \text { Korea } & 2001^{*} & 3.0 & 7.1 & 3.3 \\ & 1998 & -6.7 & 7.5 & 12.8 \\ & 1999 & 10.7 & 0.8 & 6.1 \\ & 2000^{*} & 8.8 & 2.3 & 2.4 \\ \text { Thailand } & 2001^{*} & 3.8 & 3.6 & 1.2 \\ & 1998 & -10.2 & 8.1 & 12.7 \\ & 1999 & 4.2 & 0.3 & 9.1 \\ & 2000^{*} & 4.3 & 1.5 & 7.2 \\ & 2001^{*} & 2.5 & 1.5 & 8.4 \\ & \text { *Estimated } & & & \end{array}$




\section{Table 12. Financial Restructuring in Asian Crisis Countries}

1. Initial liquidity support to banks

2. Bank shutdowns

3. Shutdowns of non-bank financial institutions

4. Mergers of finacial institutions

5. Banks nationalized (temporarily)

6. Government provided funds for recapitalizations

7. Majority overseas ownership of banks

8. Weak financial institutions still in system

9. a- Nonperforming loans / total loans b- Nonperforming loans / total loans after transfers to asset management companies

10. Assets disposed of as a share of assets transferred to Asset Management Companies (AMCs)

11. Corporate governance + management of banks
(a) independent outside directors
(b) changes in top management, majority owned domestic banks

12. Corporate restructuring (August, 1999)
(a) out-of-court restructured debt/total debt (percent)
(b) in-court restructured debt/total debt (percent)

13. Interest difficulties of firms. Percent that cannot cover interest expense from operational cash flows 2000-02 (assuming 1999 interest rates)

14. Public debt, percent of GDP
(a) 1997
(b) 1999

15. Quality of financial sector regulation index: (4=best practice, $1=$ =weakest)
(a) 1997
(b) 1999

16. Ownership concentration + legal framework

(a) Percent, ownership of top 15 families

(b) Efficiency of judicial system, index (1=worst, 10=best)

(c) Rule of law, index (1=worst, 10=best)

(d) Corruption, index (1=worst, 10=top)

17. Market structure changes in financial sector (1999) 2
(a) Number of commercial banks: taken over/sold to foreigners/nationalized

(b) Number of private domestic banks (market share \%)

(c) Number of state banks (market share, \%)

(d) Number of non banks (market share, \%)

$\frac{\text { Indonesia }}{\$ 21.7 \text { billion }}$
$(18 \%$ of GDP $)$
70 of 237
None

4 of 7 state banks merged, and 9 banks nationalized

\begin{tabular}{lr}
\multicolumn{2}{c}{4} \\
Sovereign \\
equivalent to $\$ 67.8$ \\
billion issued
\end{tabular}

Allowed, 1 potentially

Weak commercial banks prevalent

$$
\begin{gathered}
58.8 \%(\text { Nov } / 00) \\
23.9 \%(\text { Nov } / 00) \\
7.0 \%
\end{gathered}
$$$$
\text { None }
$$$$
\text { None }
$$$$
\text { Korea }
$$$$
\$ 23.3 \text { billion }
$$$$
\text { ( } 5 \% \text { of GDP) }
$$$$
\text { None }
$$$$
>200
$$

9 of 26 taken over by other banks

$\$ 50$ billion injected into 9 commercial banks; 3 out of 5 major banks now at least $80 \%$ controlled by state 1

Allowed, 1 completed and 6 with significant foreign ownership

Many weak nonbank financial institutions

$$
\begin{gathered}
17.9 \%(\text { Sept/00) } \\
12.3 \%(\text { Sept/00) } \\
48.0 \%
\end{gathered}
$$

$2 / 3$ of board slots

6 of 11 major banks

40

8

17

4

48

98

1.3

2.0

62

2.5

4.0

2.2

$4 / 0 / 4$

122(21)

43(78)

245(1)

$\frac{\text { Thailand }}{\$ 24.1 \text { billion }}$
$(20 \%$ of GDP $)$
1 of 15
59 of 91

3 banks and 12 finance companies merged

4

$\$ 1.7$ billion injected into private banks; $\$ 12$ billion injected into public banks

Allowed, 4 completed and 2 potentially

A few weak private commercial and public banks

$26.5 \%(\mathrm{Dec} / 00)$

$17.7 \%(\mathrm{Dec} / 00)$

$70 \%$ of the assets of closed finance companies

3 of 11 banks<smiles></smiles>

7

22

40

1.0

2.7

53

3.2

6.3

5.2

$3 / 4 / 2004$

13(48)

6(45)

22(7)

Sources: Claessens et al [1999], World Bank [2000], and national sources

1 In December 2000, an additional $\$ 36$ billion was made available for banks/ non-banks financial intermediaries

2 Share of assets held by foreign banks (mid 2000) was 12\% for Indonesia; $8 \%$ for Korea; and 16\% for Thailand 
Figure 1. Relative Number of Fund Structural Conditions in Different Policy Areas

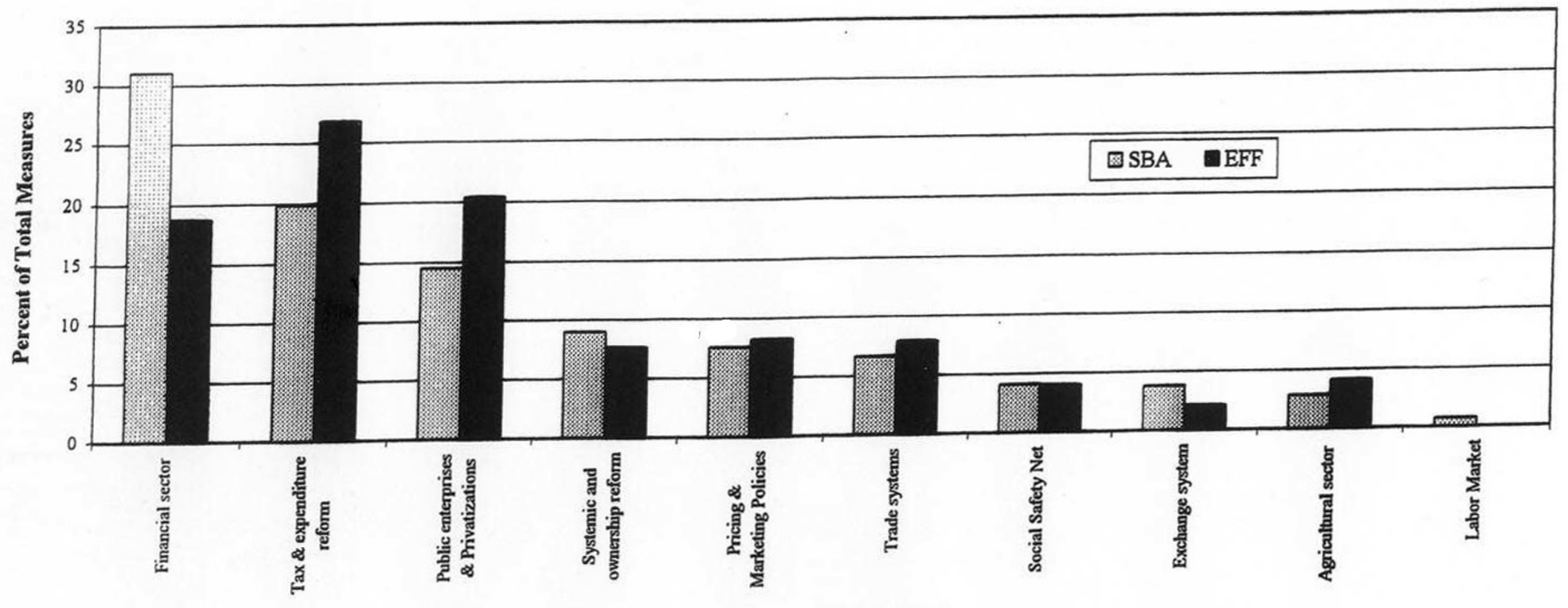




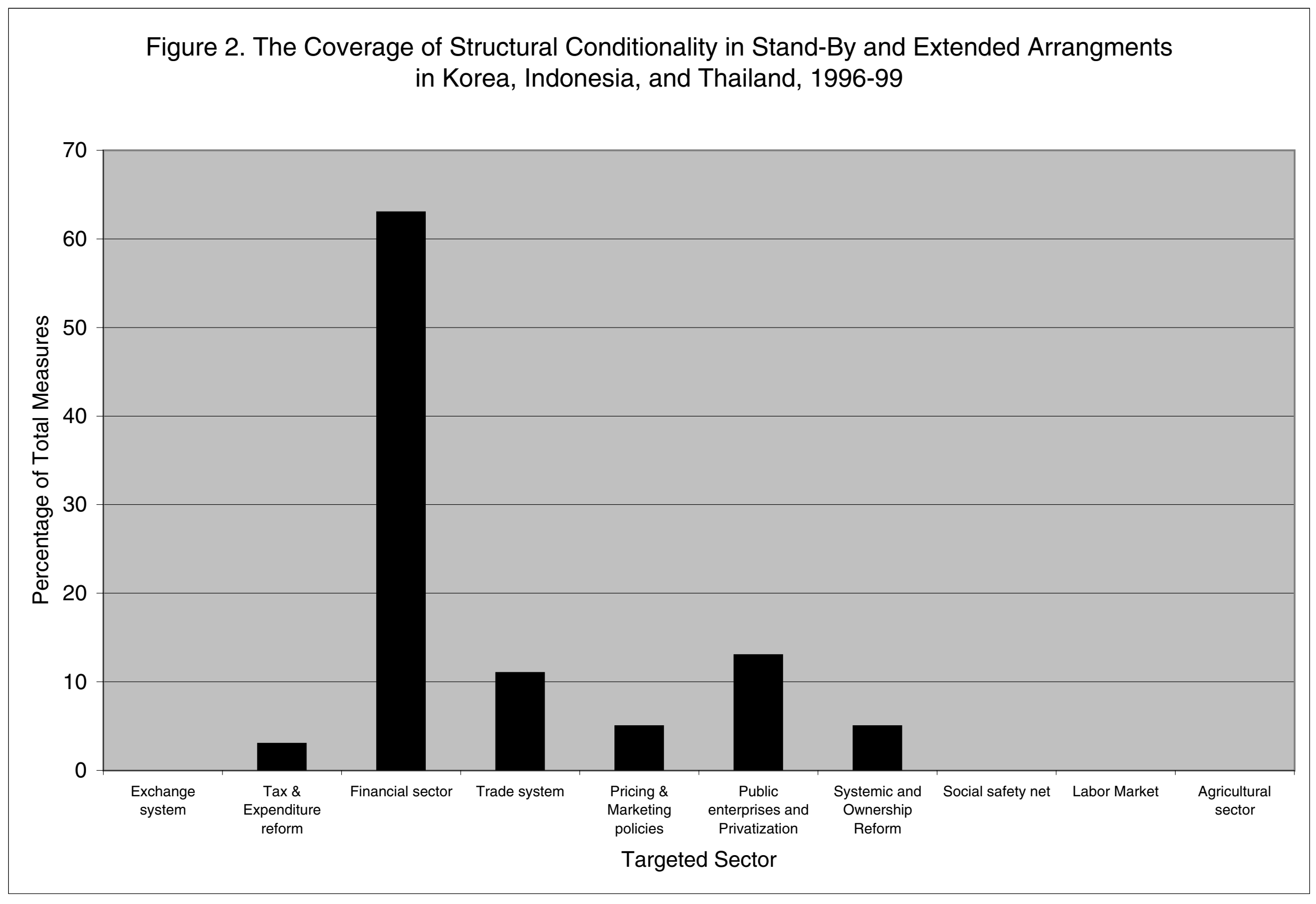




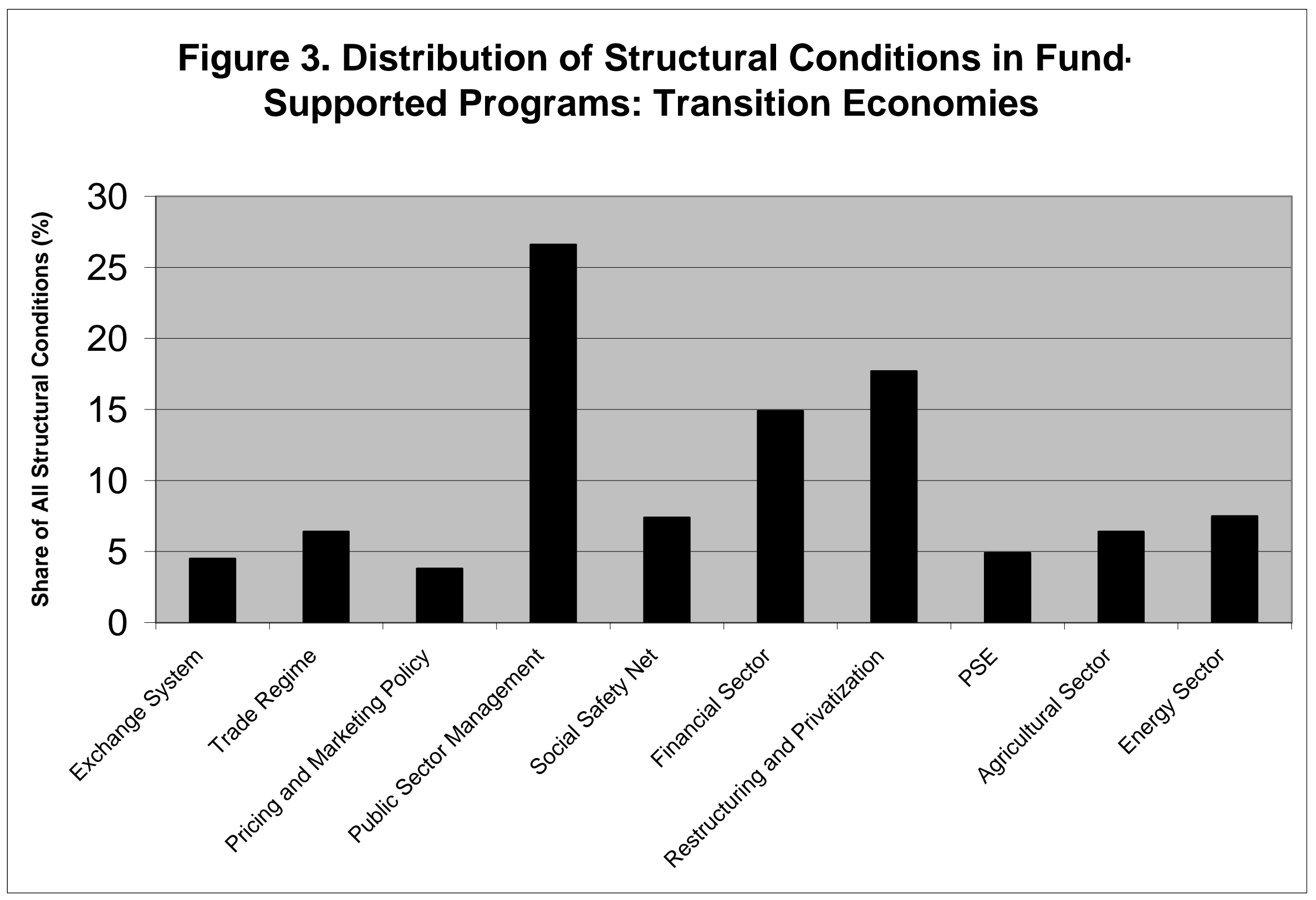

